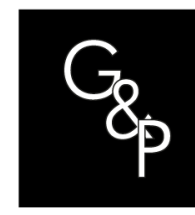

\title{
A conceptual framework for integrating the critical success factors to service innovation
}

\author{
Uma estrutura conceitual para integrar fatores críticos da inovação \\ em serviços
}

\author{
Guilherme Sales Smania ${ }^{1}$ (1), Glauco Henrique de Sousa Mendes ${ }^{1}$ (i) \\ ${ }^{1}$ Universidade Federal de São Carlos - UFSCar, Departamento de Engenharia de Produção, São Carlos, SP, Brasil. \\ E-mail: guilhermesmania@hotmail.com; glauco@dep.ufscar.br
}

Como citar: Smania, G.S., \& Mendes, G.H.S. (2020). A conceptual framework for integrating the critical success factors to service innovation. Gestão \& Produção, 28(3), e0026,

https://doi.org/10.1590/1806-9649-2021v28e26

\begin{abstract}
The literature on service innovation has identified many factors that contribute to its success. However, the literature is fragmented concerning identifying and analyzing the critical factors that lead to success in service innovation. This article has two main objectives. First, we describe, analyze, and synthesize these critical factors via a literature review of the research conducted on service innovation. Second, we outline a framework that consists of the most influential Critical Success Factors (CSFs). The systematic literature review analyzed a sample of 317 articles published between 1985 and 2018. The analysis identified 16 of the most influential critical factors that are included in a proposed conceptual framework for service innovation. This article contributes theoretically with an analysis and synthesis of the success factors for service innovation and by offering a practical tool in the form of a conceptual framework that can be used as an analytical tool by firms and their service managers. Furthermore, this study identifies new areas for research in service innovation, focusing on discovering CSFs for service innovation in manufacturing companies, the influence of specific CSFs in organizational performance, or by empirically validating our conceptual framework as well as the impact of new technologies on success innovation factors. In the conclusion, we discuss the limitations of the research and offer suggestions for future studies.
\end{abstract}

Keywords: Service innovation; New service development; Critical factors; Success; Systematic bibliographic review.

Resumo: A literatura sobre inovação em serviços tem identificado muitos fatores que contribuem para seu sucesso. No entanto, esta literatura é fragmentada no que diz respeito à identificação e análise dos fatores críticos de sucesso (FCSs) da inovação em serviços. $O$ artigo tem dois principais objetivos. Primeiro, ele descreve, analisa e sintetiza esses fatores por meio de uma revisão da literatura da pesquisa sobre inovação em serviços. Segundo, ele propõe uma estrutura conceitual que apresenta os fatores críticos mais influentes. Para atingir esses objetivos, o artigo utiliza uma revisão sistemática da literatura, considerando uma amostra de 317 artigos publicados entre 1985 a 2018. A partir da análise da literatura, foram identificados os 16 fatores críticos mais influentes, os quais formam a estrutura conceitual proposta para orientar a inovação em serviço. $O$ artigo traz uma contribuição teórica com sua análise e síntese dos fatores para inovação em serviços e uma contribuição prática com sua estrutura conceitual, a

Recebido em Maio 19, 2020 - Aceito em Jun. 22, 2020

Financial support: The São Paulo Research Foundation, FAPESP.

This is an Open Access article distributed under the terms of the Creative Commons Attribution License, which permits unrestricted use, distribution, and reproduction in any medium, provided the original work is properly cited. 
qual pode ser usada como ferramenta analítica pelas empresas e seus gerentes de serviços. Além disso, o artigo identifica novas oportunidades de pesquisa relativos à inovação de serviços com foco na descoberta de FCSs para inovação de serviços em empresas de manufatura; a influência de fatores específicos no desempenho da organização, a validação empírica da estrutura conceitual proposta e a avaliação dos impactos de novas tecnologias nos fatores críticos relativos à inovação em serviços. Para concluir, o artigo discute limitações e oferece sugestões para pesquisas futuras.

Palavras-chave: Inovação em serviços; Desenvolvimento de novos serviços; Fatores críticos; Sucesso; Revisão bibliográfica sistemática.

\section{Introduction}

Service innovation has attracted much attention in both academic circles and among organizations of various sectors. Traditional services sectors e.g. the health care sector, the hotel industry, and the financial and technological sectors have all sought out service innovation methods as a way of increasing value for their customers and to increase their competitiveness (Chen \& Tsou, 2006; Vasconcellos \& Marx, 2011; Storey et al., 2016; Tomaszewski et al., 2016). Manufacturing companies have adjusted their production centric business models to represent service-oriented models, and this trend has been called "Servitization" (Lütjen et al., 2019; Martinez et al., 2019; Sjödin et al., 2020; Queiroz et al., 2020; Vandermerwe \& Rada, 1988). Service innovation can be a great source of benefits for product and financial competitiveness for manufacturing companies (Baines et al., 2017; Mendes et al., 2017; Sjödin et al., 2020).

Academic literature on service innovation started to gain prominence in the mid1980s, stemming from studies on product innovation (Mendes et al., 2017). Witell et al. (2016) conducted a literature review on these studies to better understand the evolution of the topic, and they identify three important perspectives, Assimilation, Demarcation, and Synthesis. Concepts of product innovation were also used to explain service innovation from the Assimilation perspective (Björk, 2014; Giannopoulou et al., 2014). The Demarcation perspective holds that products and services are distinct from the other and that services innovation should therefore be treated independently. Service innovation refers to the offering of new services or an improvement in an existing service and results in specific studies on the topic (Gebauer et al., 2008; Joly et al., 2019; Salunke et al., 2011; Salunke et al., 2019). The Synthesis perspective holds that innovation encompasses both product innovations and service innovation. As such, innovation is understood as an integrated new supply that includes both products and services (Cho et al., 2012; Gustafsson et al., 2020; Joly et al., 2019; Ordanini \& Parasuraman, 2011). As the subject evolved, studies on service innovation expanded and became more diversified (Carlborg et al., 2014; Mendes et al., 2017; Storey et al., 2016).

One important discussion on the matter is the conceptualization of service innovation. Terms like service innovation and the development of new services (DNS) are sometimes used to refer to the same phenomenon (Gustafsson et al., 2020; Mendes et al., 2017). This argument is reinforced from the Synthesis perspective. For example, Biemans et al. (2016) state that DNS and service innovation are synonymous since they both deal with new services, improvements in existing services, or the process of generating innovations. Service innovation can be defined as a change in the attributes of service and/or in the competencies of the service 
provider or the customers (co-creation) (Gallouj \& Weinstein, 1997; Gustafsson et al., 2012; Salunke et al., 2011; Salunke et al., 2019). In addition, service innovation encompasses different types and modes (for example, in the content of the services itself, in the processes of delivering the service, or in other related processes) (Gallouj \& Weinstein, 1997). Service innovation can also be understood as a change in the context of services and as a restructuring of the actors and resources involved, creating value from new configurations among actors and resources (Edvardsson \& Tronvoll, 2013; Edvardsson et al., 2018; Joly et al., 2019). In summary, service innovation has evolved to include both the development and implementation of innovations, as well as the results (Carlborg et al., 2014; Witell et al., 2016; Mendes et al., 2017).

Another popular theme in the literature on service innovation derived from studies on product innovation (Ernst, 2002; Florén et al., 2018) deals with identifying the Critical Success Factors (CSFs) (Mendes et al., 2017; Biemans \& Griffin, 2018). These factors are methods or practices that are effective in generating positive results in service innovation (Biemans \& Griffin, 2018). Many CSFs have been identified in the literature, such as strategic factors (Menor \& Roth, 2008; Wikhamn et al., 2018; Zach, 2012), and organizational factors (Anning-Dorson, 2016b; Singh et al., 2020; Verdu-Jover et al., 2018; Yeh \& Walter, 2017). Another category deals with the actors involved in the innovative process for services (Alam, 2006; Alam \& Perry, 2002; Karlsson \& Skålén, 2015; Lütjen et al., 2019; Nieves \& Diaz-Meneses, 2018; Mu et al., 2018; Santos-Vijande et al., 2018). There are also factors related to the process of innovation itself (Antony et al., 2016; Arvanitis et al., 2017; Engen \& Magnusson, 2018) and those associated with capabilities, resources, and technology (Cheng et al., 2018; Divisekera \& Nguyen, 2018; Kroh et al., 2018). Even external factors can be considered CSFs, as these can sometimes stimulate postures related to service innovation (Divisekera \& Nguyen, 2018; Indounas \& Arvaniti, 2015; Thakur \& Hale, 2013).

The literature base on CSFs is quite robust, albeit fragmented. Many studies emphasize one or few factors, and this makes it difficult to develop a holistic view of the factors that effectively contribute to service innovation (Carlborg et al., 2014; Mendes et al., 2017; Storey et al., 2016). There is a gap in the literature concerning the organization of the results and the synthesis of conceptual structure that integrates CSF principles for service innovations. This synthesis could help companies improve their service innovation processes. This study sought to answer the following research questions:

RQ1: What are the main CSF characteristics for service innovation that are described in the literature?

$\mathrm{RQ2}$ : What are the main factors and how are these factors related?

This study will objectively categorize and systematize the Critical Success Factors (CSFs) to service innovation. We will also propose a conceptual structure based on the most influential CSFs and propose future research opportunities related to service innovation. A systematic bibliographic review was conducted for a sample of 317 articles published between 1985 and 2018. Two analytical approaches were used. Bibliometrics aided in forming a panoramic evaluation of existing literature, mapping the intellectual territory for the research. The content analysis aided in identifying and analyzing the CSFs. This study contributes to the 
base of literature on service innovation in three main ways: i) it identifies the CSFs for service innovation; ii) it discusses the most influential factors found in the sample (most-cited), denoting the importance of these factors; iii) it proposes a framework from the most influential factors. This framework can be used by companies in the service or manufacturing sectors to support their service innovation processes.

The article is divided into four additional sections, excluding the above introduction. The second section is dedicated to describing the research method. The third section presents the bibliographic discussions. The fourth section presents and discusses the CSFs for service innovation. The fifth section highlights opportunities for future research on service innovation and presents the conclusions, recommendations, and limitations of this study.

\section{Research method}

Articles related to CSFs for service innovations were taken from the following web databases: Web of Science (WoS) and Scopus. The searches were conducted in October and November 2018. The search words were derived from articles (Mendes et al., 2017; Santamaría et al., 2012; Storey et al., 2016) who also focused on identifying CSFs. The following search words (keywords) were used: "service innovation" OR "new service development" OR "NSD" AND "antecedents" OR "factors" OR "success" OR "performance" OR "determinants". These terms were searched for in the titles, abstracts, or keywords of the articles. The following inclusion criteria were used: i) choosing "article" and "review" type documents; ii) the documents must have been written in English, and so articles published from scientific congresses or books (documents that belong to "grey literature") were not considered, since we opted to use articles that have gone through a more rigorous review process. An initial sample size of 875 articles was returned from the Web of Science platform, and a sample of 1403 articles was returned from the Scopus platform, resulting in a total initial sample of 1699 articles.

The metadata of the articles were exported to the Mendeley support platform to manage the bibliography. The titles and abstracts of these articles were analyzed to verify if they fit the scope of the research project. Articles that discussed CSFs for service innovation were chosen and out-of-context articles were discarded. In all, 262 articles were chosen. Next, a second filter was applied after more completely analyzing the articles, e.g. analyzing the introductions, hypotheses when they were present, the results, and the conclusions (not only titles and abstracts). Twenty-six (26) articles were discarded in this second filter phase, as they did not address CSFs (Lusch \& Nambisan, 2015, for example) or because the articles were not fully available (Ansari \& Atri, 2017, for example). After this, 236 articles were selected. This sample was then further refined using the snowball method (Mendes et al., 2017 ) to obtain new articles to include in the sample. The final total was 317 articles comprising the sample.

The metadata were then exported again. All of the articles were analyzed descriptively and technically following the predefined standards. The descriptive analysis (bibliometric) used a deductive approach to classify the articles that allowed us to answer RQ1. The content analysis sought to identify the CSFs and their impacts on the type of innovation, and this was done using the NVivo 11 Plus software program. 
This allowed us to standardize the categories and compare diverse references, allowing for inclusions, modifications, and cross-referencing among the information. This resulted in the CSFs that were more apparent in literature being organized into a conceptual structure (conceptual framework). In addition, an agenda for future research into service innovation was established.

\section{Results}

\subsection{Descriptive analysis}

Figure 1 shows the frequency of publication for the articles contained in the sample. The first article was published in 1985 (Johne \& Harborne, 1985). The sample consisted of articles that spanned 34 years. Articles published early on were related to CSFs (Easingwood \& Storey, 1991; Edvardsson \& Olsson, 1996; Scheuing \& Johnson, 1989; Storey \& Easingwood, 1996), all of which were very influenced by service marketing and product development. Financial services were also heavily investigated in this early period. By contrast, articles published in the last for years, 2015 (32), 2016 (25), 2017 (14), and 2018 (39), constitute 34\% of the total sample. In 2018, thirty-nine (12\%) articles were published. We can affirm that there is increasing interest in CSFs themes recently in the scientific community in light of many innovations in the service areas, for both companies in traditional service sectors and companies in the manufacturing sector.

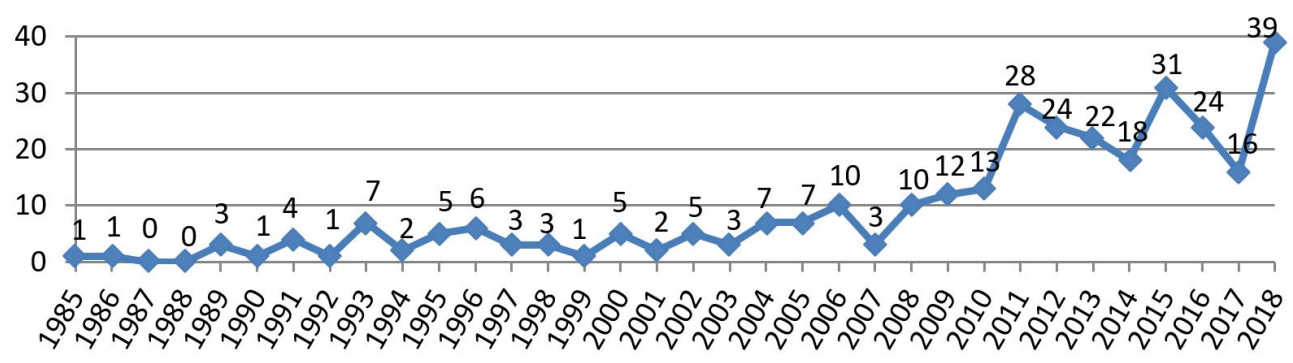

Figure 1. Graph of the frequency of publications of articles.

The scientific journals with the largest number of publications on the topic were also identified. In all, 140 different journals published articles that comprise the sample. Table 1 shows the 11 journals that had the most publications on the subject, details the knowledge area of each journal, shows the $\mathrm{H} 5$ indices, and the number of articles published per journal. As was expected, this research topic has gained attention among communities that specialize in services (service management, marketing, and operations, for example) like "The Service Industries Journal", the "Journal of Service Research", the "Journal of Services Marketing", and the "Journal of Service Management". Other journals cater to the management, innovation, and technology fields, like the "Journal of Product Innovation Management", and "Technovation". Some journals deal with business, like the "Journal of Business Research", indicating that these research communities are also giving more attention to service innovation. 
Table 1. Journals with the most publications.

\begin{tabular}{|c|c|c|c|c|c|}
\hline & Journal & Area* & H5 ${ }^{*}$ & Articles & $(\%)$ \\
\hline 1. & The Service Industries Journal & Service Management & 25 & 24 & 7.57 \\
\hline 2. & $\begin{array}{l}\text { Journal of Product Innovation } \\
\text { Management }\end{array}$ & $\begin{array}{c}\text { Innovation } \\
\text { Management }\end{array}$ & 58 & 22 & 6.94 \\
\hline 3. & Journal of Service Management $^{\star \star \star}$ & Service Management & 37 & 18 & 5.68 \\
\hline 4. & Journal of Services Marketing & Service Marketing & 36 & 13 & 4.10 \\
\hline 5. & Journal of Business Research & $\begin{array}{c}\text { Business } \\
\text { Administration }\end{array}$ & 96 & 10 & 3.15 \\
\hline 6. & Journal of Service Research & $\begin{array}{l}\text { Marketing/ Service } \\
\text { Management }\end{array}$ & 40 & 8 & 2.52 \\
\hline 7. & $\begin{array}{l}\text { Int. Journal of Contemporary } \\
\text { Hospitality Management }\end{array}$ & $\begin{array}{c}\text { Hospitality } \\
\text { Management }\end{array}$ & 53 & 7 & 2.21 \\
\hline 7. & European Journal of Marketing & Marketing & 39 & 7 & 2.21 \\
\hline 7. & Industrial Marketing Management & Marketing & 66 & 7 & 2.21 \\
\hline 7. & $\begin{array}{l}\text { International Journal of Bank } \\
\text { Marketing }\end{array}$ & Service Marketing & 36 & 7 & 2.21 \\
\hline 11. & Technovation & Quality Management & 54 & 6 & 1.89 \\
\hline
\end{tabular}

* The main area(s) of knowledge was (were) identified by consulting the website of each journal. ** The h5 index is the $\mathrm{h}$ index of articles published in the past five years. This is the largest number $\mathrm{h}$ of a publication, where $\mathrm{h}$ articles published from 2013 to 2017 have been cited at least $\mathrm{h}$ times each. Researched on Google Scholar on 08/20/2019. ${ }^{* * *}$ Before 2009, the journal was called the International Journal of Service Industry Management.

The sample was also characterized according to the regions where the studies were conducted. This characterization was not made concerning the nationality of the authors, but rather concerning the country in which the studies were carried out. Table 2 shows these results. China and Taiwan stand out among the emerging economies because they are global manufacturing and financial hubs, respectively. Many studies are coming from the United States, Germany, the U.K., and Sweden, among others. This trend can be explained by the fact that these countries have more developed economies, which give specific importance to the service sectors (Santamaría et al., 2012). We emphasize that Scandinavian countries like Sweden \& Finland in particular, are especially prolific in publishing work on service research.

Table 2. Region used for studies.

\begin{tabular}{cccc}
\hline & Country & Articles & (\%) \\
\hline 1. & Taiwan & 46 & 14.51 \\
\hline 2. & United Kingdom & 38 & 11.99 \\
\hline 3. & United States & 31 & 9.78 \\
\hline 4. & Spain & 30 & 9.46 \\
\hline 5. & China & 28 & 8.83 \\
\hline 6. & Germany & 28 & 8.83 \\
\hline 7. & Sweden & 25 & 7.89 \\
\hline 7. & Italy & 18 & 5.68 \\
\hline 9. & Finland & 18 & 5.68 \\
\hline 9. & Netherlands & 18 & 5.68 \\
\hline
\end{tabular}


A fourth characterization dealt with which service sector the research was based on. Four categories were observed. The majority $(77.60 \%)$ of the studies addressed traditional service sectors, e.g. banks (Sridhar \& Ganesan, 2015; Yang et al., 2016), hospitals (Ekingen et al., 2018), hotels (Baradarani \& Kilic, 2018; Cheng et al., 2018), and restaurants (Geng et al., 2018; Li \& Hsu, 2018). Studies on innovations to services in the manufacturing sector, product-service systems, service infusions, and servicedominated logic (Gebauer, 2008; Kroh et al., 2018; Santamaría et al., 2012) were also observed in the sample. Some studies focused only on services in this context $(9.78 \%)$ and others that address service and manufacturing businesses together (11.36\%).

The last characterization deals with the research method (Table 3). Most studies were empirical (about 95\%), that used surveys, case studies, action research, interviews, and meta-analysis. Empirical studies show a predominately quantitative approach using surveys $(69.40 \%)$, showing the operationalization maturity of the concepts related to service innovation. Only 16 articles were theoretical or conceptual studies in which the authors conducted a literature review to systematize the existing knowledge (e.g., Zhang et al., 2016), or made propositions that were to be confirmed in future studies (e.g., Sindakis \& Kitsios, 2016).

Table 3. Research methods used in the article sample.

\begin{tabular}{llcc}
\hline \multicolumn{1}{c}{ Research Method and Strategy } & Articles & (\%) \\
\hline Theoretical & Bibliographic Review & 16 & 5.05 \\
\hline Empirical & Survey'aa & 220 & 69.40 \\
\cline { 2 - 4 } & Case Study & 64 & 20.19 \\
\cline { 2 - 4 } & Interviews & 10 & 3.15 \\
\cline { 2 - 4 } & Mix (Survey and Case Study) & 4 & 1.26 \\
\cline { 2 - 4 } & Meta-analysis & 1 & 0.32 \\
\cline { 2 - 4 } & Mix (Survey e Meta-analysis) & 1 & 0.32 \\
\cline { 2 - 4 } & Research-action & 1 & 0.32 \\
\hline
\end{tabular}

\subsection{Content Analysis}

\subsubsection{Critical success factors in service innovation}

Fifty-four (54) Critical Success Factors (CSFs) were identified after the technical content analysis. There were difficulties concerning the lack of homogeneity of the terms and conceptualizations of the factors. For example, Li et al. (2018) define organizational learning as a process by which a company obtains information and creates new knowledge. Tajeddini et al. (2017) define organizational learning as beliefs and values associated with developing new knowledge, insights, and consciousness. Even though these definitions are related, they do focus on different aspects (processes and values). We opted to maintain the original intent of the authors in these cases.

We also noticed a disparity in the usage of terms referring to the same factor. For example, (Nieves \& Diaz-Meneses, 2018; Ryu \& Lee, 2018; Zhao et al., 2017) refer to technology in general as a CSF, while (Carroll, 2016; Divisekera \& Nguyen, 2018; Kroh et al., 2018) refer to information technology and communication (ITC) as a CSF. 
In these cases, we adopted the terms indicated by the authors of the articles. More of these issues will be discussed at the end of this study. Nonetheless, we were able to establish the CSFs to map the most influential factors for service innovation.

Table 4 shows the 40 CSFs that appear in at least three studies. These factors were grouped into nine-factor categories (Constructs). For example, the Strategy construct encompasses factors related to posture and strategic decision making in the company when facing service innovation (e.g. market orientation, strategy, risk-taking, and attitude towards change). The Organizational Characteristics construct deals with the attributes linking the organization to innovation (e.g. organizational design, culture, information sharing, organizational learning, etc.). Two constructs, the Leadership, and Team constructs deal with the behavior of the people involved with innovation processes but were considered independent because they deal with different actors. We opted for creating an Integration construct to join factors that promoted collaboration, involvement, and engagement between different internal or external agents (e.g. customers, front-line employees, competitors, etc.) Factors such as innovation process proficiency, formalization, and degree of innovation, were categorized into the Process construct. "Resources and Capabilities" deal with factors related to the necessary resources and capabilities for service innovation. Technology is one special type of resource, and so it was given its separate construct. External forces (e.g. market competitiveness, appeal, and public incentive policies) were the last category considered.

Table 4. Constructs of factors linked to service innovation.

\begin{tabular}{|c|c|c|}
\hline \multicolumn{2}{|l|}{ Constructs/Factors } & \multirow[t]{2}{*}{ References } \\
\hline & & \\
\hline Market Orientation & 58 & $\begin{array}{l}\text { Cheng \& Chen, 2017; Cheng \& Krumwiede, 2010; Jian \& } \\
\text { Zhou, } 2015\end{array}$ \\
\hline Strategy & 33 & $\begin{array}{l}\text { Edvardsson et al., 2013; Menor \& Roth, 2008; Wikhamn et al. } \\
\text { 2018; Zach, } 2012\end{array}$ \\
\hline Risk-taking & 4 & $\begin{array}{l}\text { Ekingen et al., 2018; Marques et al., 2015; Sridhar \& } \\
\text { Ganesan, } 2015\end{array}$ \\
\hline $\begin{array}{l}\text { Attitude toward } \\
\text { change }\end{array}$ & 3 & Oly Ndubisi \& Iftikhar, 2012; Tajeddini et al., 2017 \\
\hline \multicolumn{3}{|c|}{ Organizational Characteristic Construct (ORG) } \\
\hline $\begin{array}{l}\text { Inter-functional } \\
\text { Integration }\end{array}$ & 45 & $\begin{array}{l}\text { Nieves \& Diaz-Meneses, 2018; Okoe et al., 2018; } \\
\text { Tajeddini et al., } 2017\end{array}$ \\
\hline $\begin{array}{l}\text { Cultural } \\
\text { organization }\end{array}$ & 24 & $\begin{array}{l}\text { Anning-Dorson, 2016b; Storey et al., 2016; Verdu-Jover et al. } \\
\text { 2018; Yeh \& Walter, } 2017\end{array}$ \\
\hline $\begin{array}{l}\text { Organization } \\
\text { learning }\end{array}$ & 19 & $\begin{array}{l}\text { Cheng \& Krumwiede, 2017; Li et al., 2018; Tajeddini et al., } \\
2017\end{array}$ \\
\hline $\begin{array}{l}\text { Organizational } \\
\text { Design }\end{array}$ & 11 & $\begin{array}{l}\text { Ekingen et al., 2018; Jaakkola \& Hallin, 2018; Tajeddini et al., } \\
2017\end{array}$ \\
\hline $\begin{array}{l}\text { Awareness } \\
\text { Management }\end{array}$ & 7 & $\begin{array}{l}\text { Ordanini \& Parasuraman, 2011; Storey \& Kahn, 2010; Tai } \\
\text { Tsou, 2012; Tsou \& Chen, } 2012\end{array}$ \\
\hline Sinergy & 7 & $\begin{array}{l}\text { Nieves \& Diaz-Meneses, 2018; Okoe et al., 2018; } \\
\text { Tajeddini et al., } 2017\end{array}$ \\
\hline Autonomy & 7 & $\begin{array}{l}\text { Ekingen et al., 2018; Oly Ndubisi \& Iftikhar, 2012; Yeh \& } \\
\text { Walter, } 2017\end{array}$ \\
\hline Business Size & 7 & $\begin{array}{l}\text { De Brentani, 1995a; Divisekera \& Nguyen, 2018; } \\
\text { Wikhamn et al., } 2018\end{array}$ \\
\hline
\end{tabular}


Table 4. Continued...

\begin{tabular}{|c|c|c|}
\hline Constructs/Factors & & References \\
\hline \multicolumn{3}{|r|}{ Leadership Construct (LEAD) } \\
\hline Leadership & 26 & $\begin{array}{l}\text { Anning-Dorson, 2016b; Mu et al., 2018; Santos-Vijande et al., } \\
\text { 2018; Yeh \& Walter, } 2017\end{array}$ \\
\hline $\begin{array}{l}\text { Top Administration } \\
\text { Support }\end{array}$ & 23 & $\begin{array}{l}\text { Arcari et al., 2018; Gottfridsson, 2014; Indounas \& Arvaniti, } \\
2015\end{array}$ \\
\hline \multicolumn{3}{|r|}{ People/Team Constructs (TEAM) } \\
\hline Training & 16 & $\begin{array}{l}\text { Amusan \& Adebola Oyekunle, 2016; Chen, 2017; Divisekera \& } \\
\text { Nguyen, } 2018\end{array}$ \\
\hline $\begin{array}{l}\text { Collaborator } \\
\text { Motivation }\end{array}$ & 5 & $\begin{array}{l}\text { Hsiao et al., 2017; Ottenbacher et al., 2006; Panesar \& } \\
\text { Markeset, } 2009\end{array}$ \\
\hline $\begin{array}{l}\text { Internal } \\
\text { Environment }\end{array}$ & 4 & $\begin{array}{l}\text { Barnett et al., 2011; Okoe et al., 2018; Panesar \& Markeset, } \\
2009\end{array}$ \\
\hline $\begin{array}{l}\text { Creativity } \\
\text { (Autodidactic) }\end{array}$ & 4 & Hsiao et al., 2017; Kao et al., 2015; Marques et al., 2015 \\
\hline \multicolumn{3}{|r|}{ Integration/Cocreation Construct (COC) } \\
\hline $\begin{array}{l}\text { Customer } \\
\text { Involvement }\end{array}$ & 119 & $\begin{array}{l}\text { Diffley et al., 2018; Gustafsson et al., 2012; Santos- } \\
\text { Vijande et al., 2018; Tu et al., } 2014\end{array}$ \\
\hline $\begin{array}{l}\text { Collaboration with } \\
\text { Partners }\end{array}$ & 43 & $\begin{array}{l}\text { Divisekera \& Nguyen, 2018; Chester Goduscheit \& Faullant, } \\
\text { 2018; Nieves \& Diaz-Meneses, } 2018\end{array}$ \\
\hline $\begin{array}{l}\text { Collaboration with } \\
\text { Suppliers }\end{array}$ & 29 & Santamaría et al., 2012; Tu et al., 2014; Wang et al., 2016 \\
\hline $\begin{array}{l}\text { Front-line } \\
\text { employees } \\
\text { involvment }\end{array}$ & 27 & $\begin{array}{l}\text { De Brentani, 1989; Engen \& Magnusson, 2018; Mu et al., } \\
\text { 2018; Siahtiri, } 2018\end{array}$ \\
\hline $\begin{array}{l}\text { Collaboration with } \\
\text { Competitors }\end{array}$ & 20 & $\begin{array}{l}\text { Chu et al., 2018; Feng \& Sivakumar, 2016; Segarra-Ciprés \& } \\
\text { Bou-Llusar, } 2018\end{array}$ \\
\hline $\begin{array}{l}\text { Collaboration with } \\
\text { Research } \\
\text { Institutions }\end{array}$ & 9 & $\begin{array}{l}\text { Feng \& Sivakumar, 2016; Segarra-Ciprés \& Bou-Llusar, 2018; } \\
\text { Thanasopon et al., } 2018\end{array}$ \\
\hline $\begin{array}{l}\text { Collaboration with } \\
\text { Foreign Partners }\end{array}$ & 3 & $\begin{array}{l}\text { Love et al., 2010; Rodríguez et al., 2018; Vendrell- } \\
\text { Herrero et al., } 2018\end{array}$ \\
\hline \multicolumn{3}{|r|}{ Process Construct (PROC) } \\
\hline Formalization & 15 & $\begin{array}{l}\text { De Brentani, 1993; Edvardsson et al., 2013; Prajogo \& } \\
\text { McDermott, } 2014\end{array}$ \\
\hline DNS Proficiency & 7 & $\begin{array}{l}\text { Indounas \& Arvaniti, 2015; Sillanpää \& Junnonen, 2012; } \\
\text { Storey \& Hughes, } 2013\end{array}$ \\
\hline Innovativeness & 5 & $\begin{array}{l}\text { Chen et al., 2009; Dotzel et al., 2013; Panesar \& Markeset, } \\
2009\end{array}$ \\
\hline $\begin{array}{l}\text { Proficiency in the } \\
\text { Provision of } \\
\text { Services }\end{array}$ & 4 & $\begin{array}{l}\text { Cheng \& Krumwiede, 2017; Chuang \& Lin, 2015; Indounas \& } \\
\text { Arvaniti, } 2015\end{array}$ \\
\hline $\begin{array}{l}\text { Innovation } \\
\text { Management }\end{array}$ & 3 & $\begin{array}{l}\text { De Brentani, 1995b; Ottenbacher et al., 2006; Seegy et al., } \\
2008\end{array}$ \\
\hline \multicolumn{3}{|r|}{ Resource and Capacity Construct (RES) } \\
\hline Human Capital & 28 & $\begin{array}{l}\text { Cheng et al., 2018; Divisekera \& Nguyen, 2018; Tuzovic et al., } \\
2018\end{array}$ \\
\hline Investment in R\&D & 11 & $\begin{array}{l}\text { Leiponen, 2012; Rong \& Ming, 2014; Suh \& Kim, 2012; } \\
\text { Temel et al., } 2013\end{array}$ \\
\hline $\begin{array}{l}\text { Dynamic } \\
\text { Capabilities }\end{array}$ & 10 & Kindström et al., 2013; Janssen et al., 2016 \\
\hline $\begin{array}{l}\text { Resource } \\
\text { Availability }\end{array}$ & 8 & $\begin{array}{l}\text { Boukis, 2013; Ekingen et al., 2018; Chester Goduscheit \& } \\
\text { Faullant, } 2018\end{array}$ \\
\hline
\end{tabular}


Table 4. Continued...

\begin{tabular}{|c|c|c|}
\hline Constructs/Factors & & References \\
\hline $\begin{array}{l}\text { Marketing } \\
\text { Capabilities }\end{array}$ & 4 & $\begin{array}{l}\text { Indounas \& Arvaniti, 2015; Pérez-Cabañero et al., 2015; } \\
\text { Tang, } 2016\end{array}$ \\
\hline Social Capital & 3 & Jian \& Zhou, 2015; Tang et al., 2015; Tang, 2016 \\
\hline \multicolumn{3}{|r|}{ TEC Construct } \\
\hline $\begin{array}{l}\text { Information } \\
\text { Technology and } \\
\text { Communication } \\
\text { (ITC) }\end{array}$ & 25 & Carroll, 2016; Divisekera \& Nguyen, 2018; Kroh et al., 2018 \\
\hline Technology & 24 & $\begin{array}{l}\text { Nieves \& Diaz-Meneses, 2018; Ryu \& Lee, 2018; Zhao et al., } \\
2017\end{array}$ \\
\hline Digital Technologies & 4 & Arvanitis et al., 2017; Chou et al., 2017; Du et al., 2016; \\
\hline \multicolumn{3}{|r|}{ External Factor Construct (EXT) } \\
\hline $\begin{array}{l}\text { Market } \\
\text { Competitiveness }\end{array}$ & 12 & $\begin{array}{l}\text { Divisekera \& Nguyen, 2018; Indounas \& Arvaniti, 2015; } \\
\text { Zhao et al., } 2017\end{array}$ \\
\hline $\begin{array}{l}\text { Market } \\
\text { Attractiveness }\end{array}$ & 6 & $\begin{array}{l}\text { Kuester et al., 2013; Ottenbacher \& Gnoth, 2005; } \\
\text { Ottenbacher et al., } 2006\end{array}$ \\
\hline $\begin{array}{l}\text { Public Incentive } \\
\text { Policies }\end{array}$ & 5 & $\begin{array}{l}\text { Barnett et al., 2011; Love et al., 2010; Wu et al., 2010; } \\
\text { Zhao et al., } 2017\end{array}$ \\
\hline
\end{tabular}

Table 4 shows the main influencing factors (most-cited) independent of category. The number of citations reveals the degree of importance of the factor given by the authors, indicating the contribution to service innovation. Table 5 shows the most cited CSFs (10 or more citations), and the frequency of citations in a period of 5 years.

Table 5. Most Cited CSFs.

\begin{tabular}{|c|c|c|c|c|c|c|c|c|c|}
\hline \multirow[b]{2}{*}{ Factors } & \multirow[b]{2}{*}{ Construct } & \multirow[b]{2}{*}{ FREQ } & \multicolumn{7}{|c|}{ Evolution } \\
\hline & & & $\begin{array}{l}85- \\
89\end{array}$ & $\begin{array}{l}90- \\
94\end{array}$ & $\begin{array}{l}95- \\
99\end{array}$ & $\begin{array}{l}00- \\
04\end{array}$ & $\begin{array}{l}05- \\
09\end{array}$ & $\begin{array}{l}10- \\
14\end{array}$ & $\begin{array}{l}15- \\
18\end{array}$ \\
\hline 1. Customer Involvement & $\mathrm{COC}$ & 119 & 2 & 3 & 6 & 5 & 16 & 47 & 40 \\
\hline 2. Market Orientation & CS & 58 & 2 & 10 & 4 & 2 & 11 & 22 & 7 \\
\hline $\begin{array}{l}\text { 3. Inter-functional } \\
\text { Integration }\end{array}$ & ORG & 45 & 0 & 3 & 2 & 7 & 4 & 21 & 8 \\
\hline 4. Partner Collaboration & $\mathrm{COC}$ & 43 & 1 & 0 & 1 & 3 & 3 & 19 & 16 \\
\hline 5. Strategy & CS & 33 & 1 & 4 & 2 & 2 & 8 & 11 & 5 \\
\hline 6. Supplier Collaboration & $\mathrm{COC}$ & 29 & 1 & 1 & 0 & 2 & 4 & 13 & 8 \\
\hline 7. Human Capital & RES & 28 & 1 & 1 & 2 & 0 & 1 & 11 & 12 \\
\hline $\begin{array}{l}\text { 8. Front-line employees } \\
\text { involvement }\end{array}$ & $\mathrm{COC}$ & 27 & 1 & 0 & 3 & 3 & 1 & 8 & 11 \\
\hline 9. Leadership & LEAD & 26 & 0 & 5 & 1 & 0 & 5 & 1 & 14 \\
\hline $\begin{array}{l}\text { 10. Information } \\
\text { Technology and } \\
\text { Communication (ITC) }\end{array}$ & TEC & 25 & 0 & 0 & 0 & 1 & 5 & 12 & 7 \\
\hline 11. Technology & TEC & 24 & 0 & 5 & 1 & 1 & 2 & 5 & 10 \\
\hline $\begin{array}{l}\text { 12. Organizational } \\
\text { Culture }\end{array}$ & ORG & 24 & 0 & 0 & 2 & 2 & 4 & 6 & 10 \\
\hline $\begin{array}{l}\text { 13. Top Administration } \\
\text { Support }\end{array}$ & LEAD & 23 & 1 & 3 & 1 & 1 & 6 & 7 & 4 \\
\hline $\begin{array}{l}\text { 14. Collaboration with } \\
\text { Competitors }\end{array}$ & $\mathrm{COC}$ & 20 & 2 & 0 & 0 & 1 & 4 & 8 & 5 \\
\hline
\end{tabular}




\begin{tabular}{|c|c|c|c|c|c|c|c|c|c|}
\hline \multirow[b]{2}{*}{ Factors } & \multirow[b]{2}{*}{ Construct } & \multirow[b]{2}{*}{ FREQ } & \multicolumn{7}{|c|}{ Evolution } \\
\hline & & & $\begin{array}{l}85- \\
89\end{array}$ & $\begin{array}{l}90- \\
94\end{array}$ & $\begin{array}{l}95- \\
99\end{array}$ & $\begin{array}{l}00- \\
04\end{array}$ & $\begin{array}{l}05- \\
09\end{array}$ & $\begin{array}{l}10- \\
14\end{array}$ & $\begin{array}{l}15- \\
18\end{array}$ \\
\hline $\begin{array}{l}\text { 15. Organizational } \\
\text { Learning }\end{array}$ & ORG & 19 & 0 & 0 & 1 & 2 & 4 & 5 & 7 \\
\hline 16. Training & TEAM & 16 & 0 & 1 & 2 & 0 & 7 & 3 & 3 \\
\hline 17. Formalization & PROC & 15 & 2 & 3 & 3 & 1 & 3 & 3 & 0 \\
\hline $\begin{array}{l}\text { 18. Market } \\
\text { Competitiveness }\end{array}$ & EXT & 12 & 0 & 0 & 1 & 0 & 3 & 4 & 4 \\
\hline 19. Investment in R\&D & RES & 11 & 0 & 0 & 0 & 0 & 1 & 8 & 2 \\
\hline $\begin{array}{l}\text { 20. Organizational } \\
\text { Design }\end{array}$ & ORG & 11 & 0 & 2 & 0 & 0 & 2 & 2 & 5 \\
\hline 21. Dynamic Capabilities & RES & 10 & 0 & 0 & 0 & 0 & 0 & 2 & 8 \\
\hline
\end{tabular}

We can see the predominance of strategic factors and those related to co-creation, principally in the last decade. One possible explanation for this is the need to obtain ideas from external sources (open innovation) for developing new services that better suit the needs of the customers, and for acquiring better knowledge on process innovation (Divisekera \& Nguyen, 2018; Gustafsson et al., 2012; Santos-Vijande et al., 2018). Another explanation is the need to position innovation in services as part of a strategic competitive edge so that the organization can innovate in a more structured way (Edvardsson et al., 2013; Seegy et al., 2008; Wikhamn et al., 2018).

\subsubsection{Degree of Innovation}

The second analysis involved identifying the degree of innovation (incremental or radical) addressed in the articles from the sample (Table 6). Radical innovation is creating a new supply, while incremental innovation adds new elements to an already existing supply without altering its general structure, only modifying some characteristics related to the concept or service process (Gallouj \& Weinstein, 1997). This investigation was necessary because there is a gap in the literature in service innovation concerning the CSFs that are most associated with a determined degree of innovation (Snyder et al., 2016). CSFs are dependent on the objectives that should be achieved, which can be related to the degree of innovation (Storey et al., 2016).

Table 6. Types of service innovation.

\begin{tabular}{lccl}
\hline $\begin{array}{c}\text { Innovation } \\
\text { Type }\end{array}$ & Articles & (\%) & \multicolumn{1}{c}{ Key References } \\
\hline Radical & 15 & 4.73 & $\begin{array}{l}\text { Chester Goduscheit \& Faullant, 2018; Melton \& } \\
\text { Hartline, 2015; Perks et al., 2012 }\end{array}$ \\
\hline Incremental & 11 & 3.47 & $\begin{array}{l}\text { De Brentani, 2001; Vermeulen, 2005; } \\
\text { Vermeulen et al., 2007 }\end{array}$ \\
\hline $\begin{array}{l}\text { Radical and } \\
\text { incremental }\end{array}$ & 76 & 23.97 & $\begin{array}{l}\text { Ford et al., 2012; Myhren et al., 2018; Ottenbacher \& } \\
\text { Harrington, 2010 }\end{array}$ \\
\hline $\begin{array}{l}\text { Without } \\
\text { Specification }\end{array}$ & 215 & 67.82 & $\begin{array}{l}\text { Edvardsson et al., 1995; Martin \& Horne, 1993; } \\
\text { Mennens et al., 2018 }\end{array}$ \\
\hline
\end{tabular}

The results indicate that the degree of innovation is not specified in the majority of articles (67.82\%). For example, Mennens et al. (2018) validate the positive influence of 
knowledge management but do not specify its degree of innovation. By contrast, many articles $(23.97 \%)$ deal with two types of innovation in the same study, as was the case with Hsiao et al. (2017), who measured service innovation based on a typology proposed by Avlonitis et al. (2001). The impacts of the CSFs on the degree of innovation is not always evident, and this does not aid in understanding how the factors influence the degree of innovation. Melton \& Hartline (2015) state that customer involvement contributes to developing radical changes in services. Nonetheless, more studies are needed to obtain more evidence on the relationship between CSFs and the degree of innovation in services.

\section{Conceptual structure}

Figure 2 shows the conceptual structure that integrates the main CSFs for service innovation. The objective was to provide a holistic view of facilitators (enablers) and influencers (drivers), highlighting the CSFs that are most relevant to service innovation. The model is formed of 16 facilitators (enablers) and one influencer (driver), showing the most cited factors among the studies from the final sample (see Table 5).

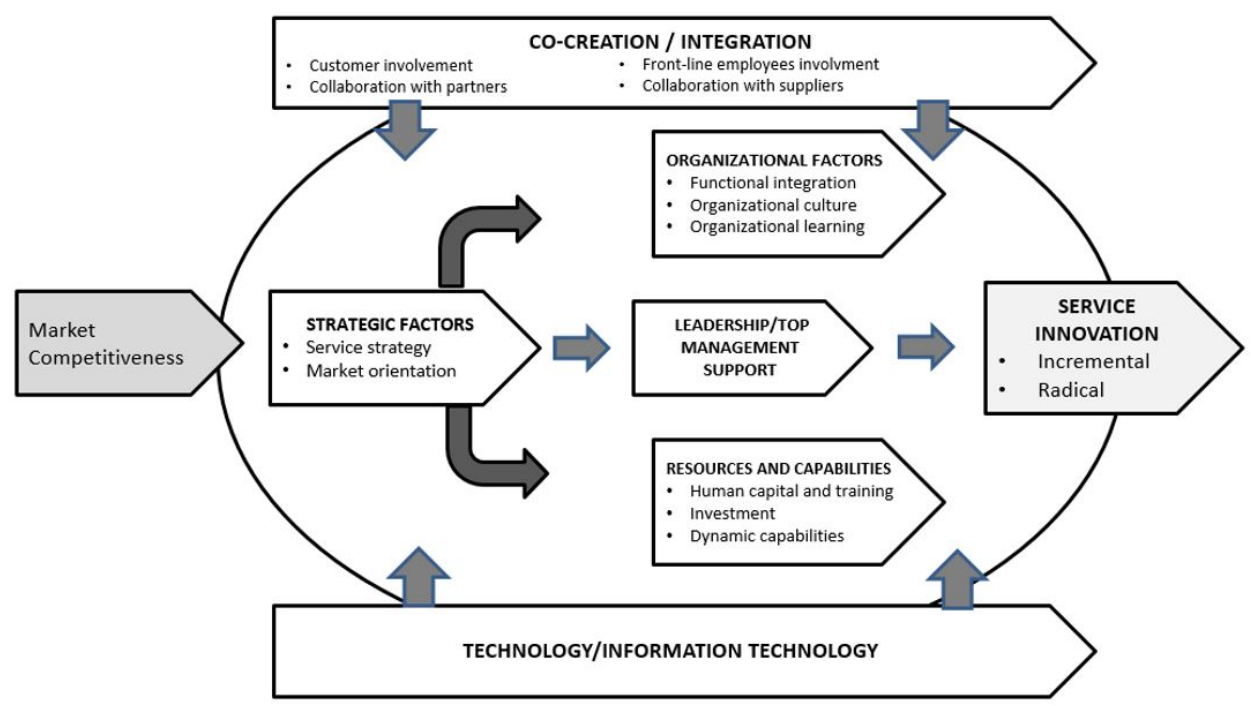

Figure 2. The theoretical model of the main success factors in service innovation.

The first facilitator is market orientation, which consists of developing a posture directed towards generation, dissemination, and responsiveness based on market intelligence (Kohli \& Jaworski, 1990; Chen et al., 2016). Organizations should not merely guarantee that external information (e.g. customer and competitors) is collected and made available, but also create an internal environment that values market responses (Cheng \& Krumwiede, 2010; Cheng \& Krumwiede, 2011). Companies in the service sector have the potential to be more oriented towards the market since they have greater contact with customers. Marketing can also be conducted using the whole organization by using front-line employees (Storey et al., 2016). According to Cheng \& Krumwiede (2012), market orientation has a positive effect, both on incremental innovation and radical innovation, being that both positively influence organizational performance. 
Market orientation should be reinforced by a service strategy, which should be a part of the competitive strategy of the company. A service strategy establishes the objectives as to the creation of services and directs how innovations will be developed (Edvardsson et al., 2013; Wikhamn et al., 2018; Zach, 2012). A clearly defined strategy allows leadership to allocate the necessary resources to innovate, and align other organizational factors and resources so that the expected results may be achieved (Edvardsson et al., 2013; Menor \& Roth, 2008). A service strategy also allows service innovations to be conducted in a more structured and consistent manner, further promoting a competitive advantage (Edvardsson et al., 2013; Seegy et al., 2008; Wikhamn et al., 2018).

Leadership is another critical factor for service innovation that is important for two reasons. First, leadership is responsible for allocating resources (human, financial, material, etc.) to promote innovation (Mu et al., 2018; Santos-Vijande et al., 2018). Second, leadership is responsible for behavior in terms of engagement and management style (Anning-Dorson, 2016b). Innovative company leaders actively participate in the innovation process and stimulate their employees to be more proactive and to take on more risk, and to think more innovatively by offering solutions to existing problems (Bhatnagar \& Kumar Gopalaswamy, 2017; Mu et al., 2018; Yeh \& Walter, 2017). Thus, strategic commitment (market orientation and service strategy) and leadership influence how practices are implemented and how resources geared towards service innovation are used. These factors are positioned at the top of the conceptual structure as a way of representing their importance in the service innovation process.

There are many factors related to organizational aspects. One of the most cited factors dealt with developing an organizational culture geared towards innovation or creating values that stimulate innovation among the employees (Anning-Dorson, 2016b; Storey et al., 2016; Verdu-Jover et al., 2018). Organizations with an innovative culture lead to favorable environments for communication and trust that contribute to sharing information and ideas among employees (Liu, 2009; Yeh \& Walter, 2017). These types of organizations also encourage employees to be more creative, take more risks, and to use available resources to implement new ideas (Yeh \& Walter, 2017). An innovative culture increases the potential for innovating with success (Anning-Dorson, 2016b; Verdu-Jover et al., 2018; Yeh \& Walter, 2017).

Functional integration promotes cooperation among sectors and leads to the spread of information (Storey et al., 2016; Nieves \& Diaz-Meneses, 2018; Tajeddini et al., 2017). It also promotes knowledge sharing that drives improved ideas and new knowledge (Okoe et al., 2018; Tajeddini et al., 2017). Functional integration contributes to increasing the innovative capacity for services (Nieves \& Diaz-Meneses, 2018; Tajeddini et al., 2017). For example, Nieves \& Diaz-Meneses (2018) state that functional integration favors developing incremental innovations since it is derived from existing knowledge in each sector. Radical innovations, by contrast, depend on external knowledge (Ordanini \& Parasuraman, 2011).

Operational learning has been recognized as an important CSF for service innovation (Hu et al., 2009; Islam et al., 2015; Kang \& Kang, 2014). Table 5 shows that many factors are related to knowledge. For example, organizational learning and knowledge management are similar concepts that are also related to functional integration and dynamic capabilities. Companies should develop processes and structures that capture, analyze, and integrate internal and external knowledge during the innovation process (Islam et al., 2015; Storey et al., 2016). All of these factors 
emphasized the importance of knowledge in the innovation process. For example, Storey et al. (2016) show that knowledge integration is critical for both service-based technology (explicit services) and people-based services (tacit services). Islam et al. (2015) also emphasize the positive impact of organizational learning on innovation for services in libraries and highlight the role of technology and organizational culture in creating knowledge.

Service innovation must be supported by resources and capabilities, and human capital, above all, should be highlighted for service companies since employees constitute the main part of the experience for tacit services (Storey et al., 2016). Human capital has knowledge abilities capacities experiences competencies and employee creativity (Cheng et al., 2018; Divisekera \& Nguyen, 2018). This is highly related to another critical Factor shown in Figure 2, which is training. Having employees trained and capacitated allows an organization to be more agile in conducting its service innovation activities since employees can generate and implement ideas in a more efficient way, and better recognize opportunities for innovation (Divisekera \& Nguyen, 2018). Human capital and training can be seen both as stimulators for innovations since they both increase the propensity to innovate (Divisekera \& Nguyen, 2018), and as factors that contribute to creating a competitive advantage since the knowledge of one employee is seen as a particular asset of the company that cannot be easily replicated by competitors (Prajogo \& Oke, 2016; Ryu \& Lee, 2016). To increase human capital companies should provide training and education to two employees and create incentives that stimulate the performance of workers (Cheng et al., 2018; Divisekera \& Nguyen, 2018; Tuzovic et al., 2018).

Service companies need both financial and human resources to promote their innovative capacity (Santamaría et al., 2012; Panesar \& Markeset, 2009). One type of capacity is particularly worth noting in Figure 2 , which is a dynamic capacity that deals with the ability of a service company to adapt to a dynamic environment (Kindström et al., 2013; Janssen et al., 2016). Competitive advantage results from the capacity of a company to i) detect opportunities and threats (sensing capacity), ii) take advantage of these opportunities (seizing capacity), and iii) maintaining competitive reconfiguration of resources (reconfiguration capacity) (Teece, 2007; Kindström et al., 2013; Janssen et al., 2016). Kindström et al. (2013) affirm that the interactions among customers and people on the front-line favor adaptation processes. However, service companies need to develop methods and tools for detecting these opportunities during these interactions with customers and reconfigure their resources to take advantage of them (Chen et al., 2015). Certainly, dynamic capacitation brings a new perspective to service innovation.

Technological advances always create opportunities for innovation in services. This is why technology, principally information technology and communication technology, have been highlighted as critical factors for service innovation (Froehle et al., 2000; Van Riel et al., 2004; Santamaría et al., 2012; Divisekera \& Nguyen, 2018; JiménezZarco et al., 2015; Kroh et al., 2018). Services that incorporate new technologies have the potential to create value for providers as well as customers (Van Riel et al., 2004). Technology facilitates the exchange of information amplified by both external and internal knowledge (Divisekera \& Nguyen, 2018; Jiménez-Zarco et al., 2015; Kroh et al., 2018). Furthermore many service innovations (explicit or tacit) require higher information than product innovations, and thus intensive use of Information Technology becomes greater as the complexity of the services being offered increases, even if the complexity of the services also increases the implementation degree of 
these technologies (Kroh et al., 2018). The service sector, like the manufacturing sector, is also influenced by new technologies. Digital technology like artificial intelligence, robots, augmented reality, etc., contribute to innovations in both the content of services and the related processes, representing an important source in service innovation (Wünderlich et al., 2015). Technology is, therefore, an important facilitator in service innovation.

Factors related to the integration/co-creation construct are among the most influential for three reasons. First, they occur simultaneously between production and consumption (Jaw et al., 2010). Consequently, customers and service providers on the front line actively participate in the co-creation of services (Engen \& Magnusson, 2018; Yang et al., 2016; Storey et al., 2016). Second, is the influence of service-dominant logic developed from the work of Vargo \& Lusch (2004), who emphasize both cocreation and networks and ecosystems for innovation. In many cases, service innovation depends on the participants of external agents that form a network of the ecosystem of innovation. (Hsueh et al., 2010; Myhren et al., 2018). Third, companies that develop service innovation rarely act alone, but rather engage in open innovation (Hsieh \& Tidd, 2012). Factors related to internal and external integration are among the most cited in the sample articles.

Employees in the front line can participate in service innovation in two ways. First, they can act as active agents, creating, developing, and implementing ideas. Second, they can act as support agents, helping others with knowledge on how to effectively conduct an innovation operation (Engen \& Magnusson, 2018). Since they are in frequent contact with customers, front-line employees can identify needs and desires (De Brentani, 1989; Siahtiri, 2018). As active agents, they can generate ideas to solve problems raised by customers (Mu et al., 2018; Siahtiri, 2018). Mu et al. (2018) also conclude that the role of these employees is more significant the greater the degree of innovation, i.e. the front-line employees are more capable of generating completely new service ideas. However, Nieves \& Diaz-Meneses (2018) state that radical innovation depends on external factors, beyond simply evolving front-line employees.

Customers are an important source of ideas for a company, as they provide feedback and suggestions for developing new services (Chen et al., 2018). Involving the customer in the innovation process benefits not only the company in terms of satisfaction, customer fidelity, and image but also in financial terms derived from this engagement (Diffley et al., 2018; Santos-Vijande et al., 2018). Gustafsson et al. (2012) state that the effect of customer involvement depends on the degree of innovation. Frequent interaction and democratic communication with customers results in incremental innovation success. For radical innovation, it is important to predict customer needs before they become expressly known (Gustafsson et al., 2012).

Given that most companies do not have the necessary resources for conducting service innovation, they often collaborate up with others, including competitors, to overcome these limitations (Kindström et al., 2014; Tsou \& Chen, 2012; Zhang et al., 2015). These resources are both tangible (technological and financial) and intangible (accumulated knowledge and acquired experience) (Divisekera \& Nguyen, 2018; Zhang et al., 2015). Cooperating with competitors in the innovative process for services has become quite common (Brandenburger \& Nalebuff, 1996). Beyond sharing knowledge, this interaction benefits companies that are involved, by sharing costs and the risks associated with the innovation process, and also creates synergy by sharing resources (Mention, 2011; Nieves \& Diaz-Meneses, 2018). Studies, like that conducted by (Divisekera \& Nguyen, 2018; Nieves \& Diaz-Meneses, 2018), confirm that 
companies who collaborate with partners have a greater tendency for introducing service innovations and achieving higher success levels.

One special type of partnership is that with suppliers (Tu et al., 2014; Wang et al., 2016). When a company interacts with its suppliers, it can obtain benefits in delivery efficiency (Tu et al., 2014). As service innovation is more vulnerable to imitation, given the intangible nature of services, collaboration with suppliers can act as a barrier to imitations (Wang et al., 2016). Cooperation with suppliers is more important for service innovation than for product innovation (Santamaría et al., 2012; Wang et al., 2016). Collaboration with suppliers, different from involving the customers, can result in greater impacts for smaller businesses, which can join together with suppliers to develop new services at lower costs and with superior quality (Tu et al., 2014).

It is important to remember that external factors also influence innovation in the service sector for CSFs as activators (Storey et al., 2016; Carlborg et al., 2014). The literature review showed various influential factors such as the level of market competitiveness (Divisekera \& Nguyen, 2018; Indounas \& Arvaniti, 2015; Sridhar \& Ganesan, 2015; Zhao et al., 2017), public policy (Barnett et al., 2011; Wu et al., 2010; Zhao et al., 2017), and customer demand (Anning-Dorson, 2016a; Thwaites \& Edgett, 1991; Vermeulen et al., 2005). However, market competitiveness was the most influential of all the factors (Divisekera \& Nguyen, 2018; Indounas \& Arvaniti, 2015; Sridhar \& Ganesan, 2015). This factor deals with the level of competition that the company must confront, which has a large impact on innovation decisions. A highly competitive environment is one characterized by many competitors all using similar inputs, and that offer products that can be easily substituted (Divisekera \& Nguyen, 2018; Indounas \& Arvaniti, 2015; Sridhar \& Ganesan, 2015; Zhao et al., 2017), which can stimulate a company to be more innovate in response to these threats.

\section{Future agenda}

As the objective of this article was to identify future areas for research on service innovation, we studied the main suggestions given by all of the articles in the sample. Four main avenues of study have been identified from this analysis.

The first deals with service innovation for manufacturing companies since many of these businesses have invested in integrated product supply and services for their customers (Kowalkowski et al., 2017; Mina et al., 2014; Baines, 2015; Queiroz et al., 2020). Services, thus, play an important role in these companies and are not merely simply added features to the products (Baines, 2015). The greater the infusion of services with the products, the more critical the innovative capacity of the company becomes (Fliess \& Lexutt, 2019). More studies are needed to address the main CSFs for manufacturing companies.

A second opportunity deals with the relationship between digital technology and service innovation. Digital technologies, like the internet of things, cloud computation, big data, remote monitoring, etc., allow service companies to develop new manufacturing services, platforms, and new business models (Ardolino et al., 2018; Frank et al., 2019). This allows companies to innovate for both service content and service delivery, i.e. have impacts on both the service itself and the process (Wünderlich et al., 2015). Future studies might show how digital technologies influence innovation practices for services since this effect is still not clearly understood. The CSFs that contribute to innovation within the digital technology and digital service context should be outlined. These studies could be aligned to the work conducted by 
Ardolino et al. (2018), who discussed data collection for products connect to the internet of things using sensors using big data to provide remote monitoring series, consulting services, and improvement services for customers.

The third opportunity deals with service innovation ecosystems. Since resources are limited (tangible and intangible) for each agent, innovation may require involving different people to integrate resources in the so-called service ecosystem (Akaka et al., 2012; Frow et al., 2014; Vargo \& Akaka, 2012). Service ecosystems deal with creating and capturing value among interrelated companies (Kohtamäki et al., 2019). Besides trading materials and products between agents, information is also shared among customers, companies, and suppliers, allowing for innovation that creates value for all agents (Frow et al., 2014). More studies are needed to explore this critical antecedent to service innovation, since the service ecosystem can benefit from developing successful new services, creating value for all agents in the ecosystem.

The fourth opportunity deals with the interaction among the company and its customers, as this is one of the main antecedents for service innovation (Chen et al., 2018). Vargo \& Lusch (2004) state that customers are an essential resource in the cocreation process of value. Companies can improve their services and refine the customer experience by considering user information. Many studies, such as those conducted by Chen et al. (2018), Diffley et al. (2018), Santos-Vijande et al. (2018), Tu et al. (2014), have already addressed the question of customer engagement in the process and how this results in service innovation. They showed the importance and value of the customer in this process, exemplifying how his/her experience is modified.

\section{Conclusions, limitation, and future studies}

This article analyzed the main success factors for service innovation employing a systematic literature review, which resulted in a sample of 317 articles for study. The content analysis identified 54 Critical Success Factors (CSFs) for service innovation, which were grouped into nine categories: strategic, organizational, leadership, people, resources and capabilities, co-creation, technology, processes, and external factors. Using the most cited studies, we developed a conceptual framework that integrated the most influential factors that can direct service companies or manufacturing companies to improve their innovation processes.

This article contributes to the base of literature and can aid researchers because it provides a synthesis of a wide range of literature related to Critical Success Factors (CSFs) for service innovation. Specifically, the conceptual framework integrates the most influential factors and emphasizes their consequences on service innovation and company performance. The results provide researchers with an in-depth look at these factors so they can analyze the relationships between different service innovation antecedents. The general implication of this study is that a conceptual framework has been developed to aid managers that seek to improve their service innovation processes. Managers can verify the status of these factors at their companies and adopt these practices to improve the performance of these critical factors, which will lead to improvements in innovation processes.

This article is limited in some ways. First, this discussion is centered around the CSFs that are in the conceptual framework. However, other CSFs may also contribute to successes in service innovation. Second, we opted to analyze and discuss only the CSFs mentioned in existing literature, in the same way, that the impacts of these factors on innovation performance were not detailed, dealing with it, rather, in a holistic way. 
We suggest that future studies discuss other factors that were identified in this study and analyze their impact on service innovation. We also suggest that future literature review analyze the impact of these factors on organizational performance. We recommend that an empirical analysis of the factors presented here in our conceptual framework be carried out to investigate the facilitators and influencers for practically employing service innovation. Lastly, we suggest that the impact of process digitalization be studied to understand its impact on service innovation.

\section{References}

Akaka, M. A., Vargo, S. L., \& Lusch, R. F. (2012). An exploration of networks in value cocreation: A service-ecosystems view. Review of Marketing Research, 9(1), 13-50. http://dx.doi.org/10.1108/S1548-6435(2012)0000009006.

Alam, I. (2006). Removing the fuzziness from the fuzzy front-end of service innovations through customer interactions. Industrial Marketing Management, 35(4), 468-480. http://dx.doi.org/10.1016/j.indmarman.2005.04.004.

Alam, I., \& Perry, C. (2002). A customer-oriented new service development process. Journal of Services Marketing, 16(6), 515-534. http://dx.doi.org/10.1108/08876040210443391.

Amusan, L., \& Adebola Oyekunle, O. (2016). Conceptualizing innovation management development through organizational learning in public service: any lessons for developing states? Problems and Perspectives in Management, 14(3), 266-275. http://dx.doi.org/10.21511/ppm.14(3-1).2016.13.

Anning-Dorson, T. (2016a). Interactivity innovations, competitive intensity, customer demand and performance. International Journal of Quality and Service Sciences, 8(4), 536-554. http://dx.doi.org/10.1108/IJQSS-11-2015-0075.

Anning-Dorson, T. (2016b). Organisational culture and leadership as mediators of service innovation and firm competitiveness: A study of an emerging economy. International Journal of Innovation Management, 20(7), 1650064. http://dx.doi.org/10.1142/S136391961650064X.

Ansari, P., \& Atri, H. (2017). Relationship between organizational culture and service innovation: an empirical case study in insurance industry. HELIX, 7(5), 1942-1949.

Antony, J., Setijono, D., \& Dahlgaard, J. J. (2016). Lean Six Sigma and Innovation-an exploratory study among UK organisations. Total Quality Management \& Business Excellence, 27(1-2), 124-140. http://dx.doi.org/10.1080/14783363.2014.959255.

Arcari, A. M., Pistoni, A., \& Peluso, S. (2018). The role of managerial control in innovation processes: an empirical analysis among Italian firms. International Journal of Business Performance Management, 19(3), 349-370. http://dx.doi.org/10.1504/IJBPM.2018.092760.

Ardolino, M., Rapaccini, M., Saccani, N., Gaiardelli, P., Crespi, G., \& Ruggeri, C. (2018). The role of digital technologies for the service transformation of industrial companies. International Journal of Production Research, 56(6), 2116-2132. http://dx.doi.org/10.1080/00207543.2017.1324224.

Arvanitis, S., Kyriakou, N., \& Loukis, E. N. (2017). Why do firms adopt cloud computing? A comparative analysis based on South and North Europe firm data. Telematics and Informatics, 34(7), 1322-1332. http://dx.doi.org/10.1016/j.tele.2016.05.013.

Avlonitis, G. J., Papastathopoulou, P. G., \& Gounaris, S. P. (2001). An empirically-based typology of product innovativeness for new financial services: success and failure scenarios. Journal of Product Innovation Management, 18(5), 324-342. http://dx.doi.org/10.1111/1540-5885.1850324. 
Baines, T. (2015). Exploring service innovation and the servitization of the manufacturing firm. Research Technology Management, 58(5), 9-11. http://dx.doi.org/10.5437/08956308X5805002.

Baines, T., Ziaee Bigdeli, A., Bustinza, O. F., Shi, V. G., Baldwin, J., \& Ridgway, K. (2017). Servitization: revisiting the state-of-the-art and research priorities. International Journal of Operations \& Production Management, 37(2), 256-278. http://dx.doi.org/10.1108/IJOPM06-2015-0312.

Baradarani, S., \& Kilic, H. (2018). Service innovation in the hotel industry: culture, behavior, performance. Service Industries Journal, 38(13-14), 897-924. http://dx.doi.org/10.1080/02642069.2017.1420172.

Barnett, J., Vasileiou, K., Djemil, F., Brooks, L., \& Young, T. (2011). Understanding innovators' experiences of barriers and facilitators in implementation and diffusion of healthcare service innovations: a qualitative study. BMC Health Services Research, 11(1), 342. http://dx.doi.org/10.1186/1472-6963-11-342. PMid:22176739.

Bhatnagar, N., \& Kumar Gopalaswamy, A. (2017). The role of a firm's innovation competence on customer adoption of service innovation. Management Research Review, 40(4), 378409. http://dx.doi.org/10.1108/MRR-11-2015-0280.

Biemans, W. G., \& Griffin, A. (2018). Innovation practices of B2B manufacturers and service providers: are they really different? Industrial Marketing Management, 75, 112-124. http://dx.doi.org/10.1016/j.indmarman.2018.04.008.

Biemans, W. G., Griffin, A., \& Moenaert, R. K. (2016). Perspective: New service development: How the field developed, its current status and recommendations for moving the field forward. Journal of Product Innovation Management, 33(4), 382-397. http://dx.doi.org/10.1111/jpim.12283.

Björk, P. (2014). The DNA of tourism service innovation: a quadruple helix approach. Journal of the Knowledge Economy, 5(1), 181-202. http://dx.doi.org/10.1007/s13132-014-0183-x.

Boukis, A. (2013). Identifying some internal S/F factors of NSD project performance. International Journal of Retail \& Distribution Management, 41(7), 531-544. http://dx.doi.org/10.1108/IJRDM-05-2013-0099.

Brandenburger, A. M., \& Nalebuff, B. J. (1996). Co-opetition. New York, Bantam Doubleday Dell Publishing Group.

Carlborg, P., Kindström, D., \& Kowalkowski, C. (2014). The evolution of service innovation research: a critical review and synthesis. Service Industries Journal, 34(5), 373-398. http://dx.doi.org/10.1080/02642069.2013.780044.

Carroll, N. (2016). So that's what the impact of IT innovation looks like? Examining the sociotechnical dynamics of public service innovation. Journal of Enterprise Information Management, 29(5), 677-705. http://dx.doi.org/10.1108/JEIM-07-2014-0072.

Chen, B. T. (2017). Service innovation performance in the hospitality industry: the role of organizational training, personal-job fit and work schedule flexibility. Journal of Hospitality Marketing \& Management, 26(5), 474-488. http://dx.doi.org/10.1080/19368623.2017.1264344.

Chen, J. S. J., \& Tsou, H. T. (2006). Information technology adoption for service innovation practices and competitive advantage: the case of financial firms. Information Research, 12(3), 7.

Chen, J. S., Kerr, D., Tsang, S. S., \& Sung, Y. C. (2015). Co-production of service innovations through dynamic capability enhancement. Service Industries Journal, 35(1-2), 96-114. http://dx.doi.org/10.1080/02642069.2014.979405.

Chen, J. S., Tsou, H. T., \& Huang, A. Y. H. (2009). Service delivery innovation: antecedents and impact on firm performance. Journal of Service Research, 12(1), 36-55. http://dx.doi.org/10.1177/1094670509338619. 
Chen, J. S., Weng, H. H., \& Huang, C. L. (2018). A multilevel analysis of customer engagement, its antecedents, and the effects on service innovation. Total Quality Management \& Business Excellence, 29(3-4), 410-428. http://dx.doi.org/10.1080/14783363.2016.1203249.

Chen, K. H., Wang, C. H., Huang, S. Z., \& Shen, G. C. (2016). Service innovation and new product performance: the influence of market-linking capabilities and market turbulence. International Journal of Production Economics, 172, 54-64. http://dx.doi.org/10.1016/j.jpe.2015.11.004.

Cheng, C. C., \& Krumwiede, D. (2010). The effects of market orientation and service innovation on service industry performance: an empirical study. Operations Management Research, 3(3-4), 161-171. http://dx.doi.org/10.1007/s12063-010-0039-x.

Cheng, C. C., \& Krumwiede, D. (2011). The effects of market orientation on new service performance: the mediating role of innovation. International Journal of Services Technology and Management, 16(1), 49-73. http://dx.doi.org/10.1504/IJSTM.2011.041977.

Cheng, C. C., \& Krumwiede, D. (2012). The role of service innovation in the market orientation: new service performance linkage. Technovation, 32(7-8), 487-497. http://dx.doi.org/10.1016/j.technovation.2012.03.006.

Cheng, C. C., \& Krumwiede, D. (2017). What makes a manufacturing firm effective for service innovation? The role of intangible capital under strategic and environmental conditions. International Journal of Production Economics, 193, 113-122. http://dx.doi.org/10.1016/j.ijpe.2017.07.007.

Cheng, J. S., Xiang, Y., Sher, P. J., \& Liu, C. W. (2018). Artistic intervention, intellectual capital, and service innovation: a case study of a Taiwan's hotel. Service Business, 12(1), 169-201. http://dx.doi.org/10.1007/s11628-017-0342-9.

Cheng, T. D., \& Chen, C. V. (2017). Does service innovation matter? An empirical study on market orientation and supply chain performance. South African Journal of Business Management, 48(1), 11-22. http://dx.doi.org/10.4102/sajbm.v48i1.16.

Cho, I., Park, H., \& Kim, J. K. (2012). The moderating effect of innovation protection mechanisms on the competitiveness of service firms. Service Business, 6(3), 369-386. http://dx.doi.org/10.1007/s11628-012-0140-3.

Chou, C. Y., Chen, J. S., \& Liu, Y. P. (2017). Inter-firm relational resources in cloud service adoption and their effect on service innovation. Service Industries Journal, 37(3-4), 256276. http://dx.doi.org/10.1080/02642069.2017.1311869.

Chu, Z., Feng, B., \& Lai, F. (2018). Logistics service innovation by third party logistics providers in China: aligning guanxi and organizational structure. Transportation Research Part E, Logistics and Transportation Review, 118, 291-307. http://dx.doi.org/10.1016/j.tre.2018.08.007.

Chuang, S. H., \& Lin, H. N. (2015). Co-creating e-service innovations: Theory, practice, and impact on firm performance. International Journal of Information Management, 35(3), 277291. http://dx.doi.org/10.1016/j.jijnfomgt.2015.01.002.

De Brentani, U. (1989). Success and failure in new industrial services. Journal of Product Innovation Management, 6(4), 239-258. http://dx.doi.org/10.1111/1540-5885.640239.

De Brentani, U. (1993). The new product process in financial services: strategy for success. International Journal of Bank Marketing, 11(3), 15-22. http://dx.doi.org/10.1108/02652329310027675.

De Brentani, U. (1995a). Firm size: implications for achieving success in new industrial services. Journal of Marketing Management, 11(1-3), 207-225. http://dx.doi.org/10.1080/0267257X.1995.9964338.

De Brentani, U. (1995b). New industrial service development: scenarios for success and failure. Journal of Business Research, 32(2), 93-103. http://dx.doi.org/10.1016/01482963(93)00040-8. 
De Brentani, U. (2001). Innovative versus incremental new business services: different keys for achieving success. Journal of Product Innovation Management, 18(3), 169-187. http://dx.doi.org/10.1111/1540-5885.1830169.

Diffley, S., McCole, P., \& Carvajal-Trujillo, E. (2018). Examining social customer relationship management among Irish hotels. International Journal of Contemporary Hospitality Management, 30(2), 1072-1091. http://dx.doi.org/10.1108/IJCHM-08-2016-0415.

Divisekera, S., \& Nguyen, V. K. (2018). Determinants of innovation in tourism evidence from Australia. Tourism Management, 67, 157-167. http://dx.doi.org/10.1016/j.tourman.2018.01.010.

Dotzel, T., Shankar, V., \& Berry, L. L. (2013). Service innovativeness and firm value. JMR, Journal of Marketing Research, 50(2), 259-276. http://dx.doi.org/10.1509/jmr.10.0426.

Du, L., Huang, Q., Yeung, K., \& Jian, Z. (2016). Improving Service Innovation Performance through the Big Data Management Closed Loop Competence in China Mobile. IJCSA, 13(1), 116-132.

Easingwood, C. J., \& Storey, C. (1991). Success factors for new consumer financial services. International Journal of Bank Marketing, 9(1), 3-10. http://dx.doi.org/10.1108/02652329110136847.

Edvardsson, B., \& Olsson, J. (1996). Key concepts for new service development. Service Industries Journal, 16(2), 140-164. http://dx.doi.org/10.1080/02642069600000019.

Edvardsson, B., \& Tronvoll, B. (2013). A new conceptualization of service innovation grounded in S-D logic and service systems. International Journal of Quality and Service Sciences, 5(1), 19-31. http://dx.doi.org/10.1108/17566691311316220.

Edvardsson, B., Frow, P., Jaakkola, E., Keiningham, T. L., Koskela-Huotari, K., Mele, C., \& Tombs, A. (2018). Examining how context change foster service innovation. Journal of Service Management, 29(5), 932-955. http://dx.doi.org/10.1108/JOSM-04-2018-0112.

Edvardsson, B., Haglund, L., \& Mattsson, J. (1995). Analysis, planning, improvisation and control in the development of new services. International Journal of Service Industry Management, 6(2), 24-35. http://dx.doi.org/10.1108/09564239510084923.

Edvardsson, B., Meiren, T., Schäfer, A., \& Witell, L. (2013). Having a strategy for new service development-does it really matter? Journal of Service Management, 24(1), 25-44. http://dx.doi.org/10.1108/09564231311304170.

Ekingen, E., Ekemen, M. A., Yildiz, A., \& Korkmazer, F. (2018). The Effect of Intrapreneurship and Organizational Factors on the Innovation Performance in Hospital. Revista de Cercetare si Interventie Sociala, 62, 196-219.

Engen, M., \& Magnusson, P. (2018). Casting for service innovation: the roles of frontline employees. Creativity and Innovation Management, 27(3), 255-269. http://dx.doi.org/10.1111/caim.12263.

Ernst, H. (2002). Success factors of new product development: a review of the empirical literature. International Journal of Management Reviews, 4(1), 1-40. http://dx.doi.org/10.1111/1468-2370.00075.

Feng, C., \& Sivakumar, K. (2016). The role of collaboration in service innovation across manufacturing and service sectors. Service Science, 8(3), 263-281. http://dx.doi.org/10.1287/serv.2016.0135.

Fliess, S., \& Lexutt, E. (2019). How to be successful with servitization-Guidelines for research and management. Industrial Marketing Management, 78, 58-75. http://dx.doi.org/10.1016/j.indmarman.2017.11.012.

Florén, H., Frishammar, J., Parida, V., \& Wincent, J. (2018). Critical success factors in early new product development: a review and a conceptual model. The International Entrepreneurship and Management Journal, 14(2), 411-427. http://dx.doi.org/10.1007/s11365-017-0458-3. 
Ford, R. C., Edvardsson, B., Dickson, D., \& Enquist, B. (2012). Managing the innovation cocreation challenge. Organizational Dynamics, 4(41), 281-290.

http://dx.doi.org/10.1016/j.orgdyn.2012.08.003.

Frank, A. G., Mendes, G. H., Ayala, N. F., \& Ghezzi, A. (2019). Servitization and Industry 4.0 convergence in the digital transformation of product firms: A business model innovation perspective. Technological Forecasting and Social Change, 141, 341-351. http://dx.doi.org/10.1016/j.techfore.2019.01.014.

Froehle, C. M., Roth, A. V., Chase, R. B., \& Voss, C. A. (2000). Antecedents of new service development effectiveness: an exploratory examination of strategic operations choices. Journal of Service Research, 3(1), 3-17. http://dx.doi.org/10.1177/109467050031001.

Frow, P., McColl-Kennedy, J. R., Hilton, T., Davidson, A., Payne, A., \& Brozovic, D. (2014). Value propositions: A service ecosystems perspective. Marketing Theory, 14(3), 327-351. http://dx.doi.org/10.1177/1470593114534346.

Gallouj, F., \& Weinstein, O. (1997). Innovation in services. Research Policy, 26(4-5), 537-556. http://dx.doi.org/10.1016/S0048-7333(97)00030-9.

Gebauer, H. (2008). Identifying service strategies in product manufacturing companies by exploring environment-strategy configurations. Industrial Marketing Management, 37(3), 278-291. http://dx.doi.org/10.1016/j.indmarman.2007.05.018.

Gebauer, H., Krempl, R., Fleisch, E., \& Friedli, T. (2008). Innovation of product-related services. Managing Service Quality, 18(4), 387-404. http://dx.doi.org/10.1108/09604520810885626.

Geng, Z., Li, C., Bi, K., Zheng, H., \& Yang, X. (2018). Motivating service employee creativity: regulatory focus and emotional labour. Journal of Service Theory and Practice, 28(2), 228249. http://dx.doi.org/10.1108/JSTP-11-2016-0214.

Giannopoulou, E., Gryszkiewicz, L., \& Barlatier, P. J. (2014). Creativity for service innovation: a practice-based perspective. Managing Service Quality, 24(1), 23-44. http://dx.doi.org/10.1108/MSQ-03-2013-0044.

Chester Goduscheit, R., \& Faullant, R. (2018). Paths toward radical service innovation in manufacturing companies: A service-dominant logic perspective. Journal of Product Innovation Management, 35(5), 701-719. http://dx.doi.org/10.1111/jpim.12461.

Gottfridsson, P. (2014). Different actors' roles in small companies service innovation. Journal of Services Marketing, 28(7), 547-557. http://dx.doi.org/10.1108/JSM-04-2013-0082.

Gustafsson, A., Kristensson, P., \& Witell, L. (2012). Customer co-creation in service innovation: a matter of communication? Journal of Service Management, 23(3), 311-327. http://dx.doi.org/10.1108/09564231211248426.

Gustafsson, A., Snyder, H., \& Witell, L. (2020). Service Innovation: A new conceptualization and path forward. Journal of Service Research, 1(2), 5. http://dx.doi.org/10.1177/1094670520908929.

Hsiao, C., Lee, Y. H., \& Hsu, H. H. (2017). Motivated or empowering antecedents to drive service innovation? Service Industries Journal, 37(1), 5-30. http://dx.doi.org/10.1080/02642069.2017.1284203.

Hsieh, K. N., \& Tidd, J. (2012). Open versus closed new service development: the influences of project novelty. Technovation, 32(11), 600-608. http://dx.doi.org/10.1016/j.technovation.2012.07.002.

Hsueh, J. T., Lin, N. P., \& Li, H. C. (2010). The effects of network embeddedness on service innovation performance. Service Industries Journal, 30(10), 1723-1736. http://dx.doi.org/10.1080/02642060903100398.

Hu, M. L. M., Horng, J. S., \& Sun, Y. H. C. (2009). Hospitality teams: knowledge sharing and service innovation performance. Tourism Management, 30(1), 41-50.

http://dx.doi.org/10.1016/j.tourman.2008.04.009. 
Indounas, K., \& Arvaniti, A. (2015). Success factors of new health-care services. Journal of Product and Brand Management, 24(7), 693-705. http://dx.doi.org/10.1108/JPBM-04-20140541.

Islam, M. A., Agarwal, N. K. K., \& Ikeda, M. (2015). Knowledge management for service innovation in academic libraries: A qualitative study. Library Management, 36(1-2), 40-57. http://dx.doi.org/10.1108/LM-08-2014-0098.

Jaakkola, E., \& Hallin, A. (2018). Organizational structures for new service development. Journal of Product Innovation Management, 35(2), 280-297. http://dx.doi.org/10.1111/jpim.12399.

Janssen, M. J., Castaldi, C., \& Alexiev, A. (2016). Dynamic capabilities for service innovation: conceptualization and measurement. $R$ \& D Management, 46(4), 797-811. http://dx.doi.org/10.1111/radm.12147.

Jaw, C., Lo, J. Y., \& Lin, Y. H. (2010). The determinants of new service development: service characteristics, market orientation, and actualizing innovation effort. Technovation, 30(4), 265-277. http://dx.doi.org/10.1016/j.technovation.2009.11.003.

Jian, Z., \& Zhou, Y. (2015). Corporate social capital, market orientation, organizational learning and service innovation performance: an empirical survey in the Pearl river delta of China. Journal of Industrial Engineering and Management, 8(2), 303-321. http://dx.doi.org/10.3926/jiem.1318.

Jiménez-Zarco, A. I., González-González, I., Martínez-Ruíz, M. P., \& Izquierdo-Yusta, A. (2015). New service innovation success: analyzing the influence of performance indicator nature. Computers in Human Behavior, 51, 1024-1031. http://dx.doi.org/10.1016/j.chb.2014.09.046.

Johne, F. A., \& Harborne, P. (1985). How large commercial banks manage product innovation. International Journal of Bank Marketing, 3(1), 54-71. http://dx.doi.org/10.1108/eb010750.

Joly, M. P., Teixeira, J. G., Patrício, L., \& Sangiorgi, D. (2019). Leveraging service design as a multidisciplinary approach to service innovation. Journal of Service Management, 30(6), 681-715. http://dx.doi.org/10.1108/JOSM-07-2017-0178.

Kang, K. H., \& Kang, J. (2014). Do External Knowledge Sourcing Modes Matter for Service Innovation? Empirical Evidence from S outh K orean Service Firms. Journal of Product Innovation Management, 31(1), 176-191. http://dx.doi.org/10.1111/jpim.12087.

Kao, P. J., Pai, P., Lin, T., \& Zhong, J. Y. (2015). How transformational leadership fuels employees' service innovation behavior. Service Industries Journal, 35(7-8), 448-466. http://dx.doi.org/10.1080/02642069.2015.1015519.

Karlsson, J., \& Skålén, P. (2015). Exploring front-line employee contributions to service innovation. European Journal of Marketing, 49(9-10), 1346-1365. http://dx.doi.org/10.1108/EJM-10-2012-0568.

Kindström, D., Kowalkowski, C., \& Mustak, M. (2014). Service innovation in networks: a systematic review and implications for business-to-business service innovation research. Journal of Business and Industrial Marketing, 29(2), 151-163. http://dx.doi.org/10.1108/JBIM-05-2013-0122.

Kindström, D., Kowalkowski, C., \& Sandberg, E. (2013). Enabling service innovation: A dynamic capabilities approach. Journal of Business Research, 66(8), 1063-1073. http://dx.doi.org/10.1016/j.jbusres.2012.03.003.

Kohli, A. K., \& Jaworski, B. J. (1990). Market orientation: the construct, research propositions, and managerial implications. Journal of Marketing, 54(2), 1-18. http://dx.doi.org/10.1177/002224299005400201.

Kohtamäki, M., Parida, V., Oghazi, P., Gebauer, H., \& Baines, T. (2019). Digital servitization business models in ecosystems: A theory of the firm. Journal of Business Research, 104, 380-392. http://dx.doi.org/10.1016/j.jbusres.2019.06.027. 
Kowalkowski, C., Gebauer, H., Kamp, B., \& Parry, G. (2017). Servitization and deservitization: Overview, concepts, and definitions. Industrial Marketing Management, 60, 4-10. http://dx.doi.org/10.1016/j.indmarman.2016.12.007.

Kroh, J., Luetjen, H., Globocnik, D., \& Schultz, C. (2018). Use and efficacy of information technology in innovation processes: the specific role of servitization. Journal of Product Innovation Management, 35(5), 720-741. http://dx.doi.org/10.1111/jpim.12445.

Kuester, S., Schuhmacher, M. C., Gast, B., \& Worgul, A. (2013). Sectoral heterogeneity in new service development: an exploratory study of service types and success factors. Journal of Product Innovation Management, 30(3), 533-544. http://dx.doi.org/10.1111/jpim.12005.

Leiponen, A. (2012). The benefits of R\&D and breadth in innovation strategies: a comparison of Finnish service and manufacturing firms. Industrial and Corporate Change, 21(5), 12551281. http://dx.doi.org/10.1093/icc/dts022.

$\mathrm{Li}, \mathrm{M} .$, \& Hsu, C. H. (2018). Customer participation in services and employee innovative behavior. International Journal of Contemporary Hospitality Management, 30(4), 21122131. http://dx.doi.org/10.1108/IJCHM-08-2016-0465.

Li, M., Jian, Z., Li, L., \& Yeung, T. K. H. (2018). Effects of organisational learning on service innovation performance: the mediating effect of supply chain collaboration and the moderating role of interpersonal trust. International Journal of Services Technology and Management, 24(1-3), 43-61. http://dx.doi.org/10.1504/IJSTM.2018.090350.

Liu, S. (2009). Organizational culture and new service development performance: insights from knowledge intensive business service. International Journal of Innovation Management, 13(03), 371-392. http://dx.doi.org/10.1142/S1363919609002340.

Love, J. H., Roper, S., \& Hewitt-Dundas, N. (2010). Service innovation, embeddedness and business performance: evidence from Northern Ireland. Regional Studies, 44(8), 983-1004. http://dx.doi.org/10.1080/00343400903401568.

Lusch, R. F., \& Nambisan, S. (2015). Service innovation: A service-dominant logic perspective. Management Information Systems Quarterly, 39(1), 155-176. http://dx.doi.org/10.25300/MISQ/2015/39.1.07.

Lütjen, H., Schultz, C., Tietze, F., \& Urmetzer, F. (2019). Managing ecosystems for service innovation: A dynamic capability view. Journal of Business Research, 104, 506-519. http://dx.doi.org/10.1016/j.jbusres.2019.06.001.

Marques, C. S., Marques, C. P., Nogueira, F., Gerry, C., \& Andrade, S. (2015). Facets and outcomes of healthcare service innovation: a study of catholic service providers in Northern Portugal. International Journal of Innovation and Learning, 18(1), 23-44. http://dx.doi.org/10.1504/IJIL.2015.070243.

Martin, C. R. M. C. R., \& Horne, D. A. (1993). Services innovation: successful versus unsuccessful firms. International Journal of Service Industry Management, 4(1). https://doi.org/10.1108/09564239310024985

Martinez, V., Neely, A., Velu, C., Leinster-Evans, S., \& Bisessar, D. (2019). Exploring the journey to services. In Handbook of service science (pp. 377-407, Vol. 2). Cham: Springer. http://dx.doi.org/10.1007/978-3-319-98512-1_17

Melton, H., \& Hartline, M. D. (2015). Customer and employee co-creation of radical service innovations. Journal of Services Marketing, 29(2), 112-123. http://dx.doi.org/10.1108/JSM02-2014-0048.

Mendes, G. H., Oliveira, M. G., Gomide, E. H., \& Nantes, J. F. D. (2017). Uncovering the structures and maturity of the new service development research field through a bibliometric study (1984-2014). Journal of Service Management, 28(1), 182-223. http://dx.doi.org/10.1108/JOSM-07-2015-0230.

Mennens, K., Van Gils, A., Odekerken-Schröder, G., \& Letterie, W. (2018). Exploring antecedents of service innovation performance in manufacturing SMEs. International Small Business Journal, 36(5), 500-520. http://dx.doi.org/10.1177/0266242617749687. 
Menor, L. J., \& Roth, A. V. (2008). New service development competence and performance: an empirical investigation in retail banking. Production and Operations Management, 17(3), 267-284. http://dx.doi.org/10.3401/poms.1080.0034.

Mention, A. L. (2011). Co-operation and co-opetition as open innovation practices in the service sector: which influence on innovation novelty? Technovation, 31(1), 44-53. http://dx.doi.org/10.1016/j.technovation.2010.08.002.

Mina, A., Bascavusoglu-Moreau, E., \& Hughes, A. (2014). Open service innovation and the firm's search for external knowledge. Research Policy, 43(5), 853-866. http://dx.doi.org/10.1016/j.respol.2013.07.004.

Mu, Y., Bossink, B., \& Vinig, T. (2018). Employee involvement in ideation and healthcare service innovation quality. Service Industries Journal, 38(1-2), 67-86. http://dx.doi.org/10.1080/02642069.2017.1374374.

Myhren, P., Witell, L., Gustafsson, A., \& Gebauer, H. (2018). Incremental and radical open service innovation. Journal of Services Marketing, 32(2), 101-112. http://dx.doi.org/10.1108/JSM-04-2016-0161.

Oly Ndubisi, N., \& Iftikhar, K. (2012). Relationship between entrepreneurship, innovation and performance. Journal of Research in Marketing and Entrepreneurship, 14(2), 214-236. http://dx.doi.org/10.1108/14715201211271429.

Nieves, J., \& Diaz-Meneses, G. (2018). Knowledge sources and innovation in the hotel industry. International Journal of Contemporary Hospitality Management, 30(6), 2537-2561. http://dx.doi.org/10.1108/IJCHM-07-2016-0341.

Okoe, A. F., Boateng, H., Narteh, B., \& Boakye, R. O. (2018). Examining human resource practice outcomes and service innovation. Service Industries Journal, 38(7-8), 431-445. http://dx.doi.org/10.1080/02642069.2017.1397636.

Ordanini, A., \& Parasuraman, A. (2011). Service innovation viewed through a service-dominant logic lens: a conceptual framework and empirical analysis. Journal of Service Research, 14(1), 3-23. http://dx.doi.org/10.1177/1094670510385332.

Ottenbacher, M. C., \& Gnoth, J. (2005). How to develop successful hospitality innovation. The Cornell Hotel and Restaurant Administration Quarterly, 46(2), 205-222. http://dx.doi.org/10.1177/0010880404271097.

Ottenbacher, M. C., \& Harrington, R. J. (2010). Strategies for achieving success for innovative versus incremental new services. Journal of Services Marketing, 24(1), 3-15. http://dx.doi.org/10.1108/08876041011017853.

Ottenbacher, M. C., Shaw, V., \& Lockwood, A. (2006). An investigation of the factors affecting innovation performance in chain and independent hotels. Journal of Quality Assurance in Hospitality \& Tourism, 6(3-4), 113-128. http://dx.doi.org/10.1300/J162v06n03_07.

Panesar, S. S., \& Markeset, T. (2009). Industrial services innovation process: influencing factors-a case study. International Journal of Services Technology and Management, 11(1), 82-102. http://dx.doi.org/10.1504/IJSTM.2009.022383.

Pérez-Cabañero, C., Cruz-Ros, S., \& González-Cruz, T. (2015). The contribution of dynamic marketing capabilities to service innovation and performance. International Journal of Business Environment, 7(1), 61-78. http://dx.doi.org/10.1504/IJBE.2015.065996.

Perks, H., Gruber, T., \& Edvardsson, B. (2012). Co-creation in radical service innovation: a systematic analysis of microlevel processes. Journal of Product Innovation Management, 29(6), 935-951. http://dx.doi.org/10.1111/j.1540-5885.2012.00971.x.

Prajogo, D. I., \& McDermott, C. M. (2014). Antecedents of service innovation in SMEs: comparing the effects of external and internal factors. Journal of Small Business Management, 52(3), 521-540. http://dx.doi.org/10.1111/jsbm.12047. 
Prajogo, D. I., \& Oke, A. (2016). Human capital, service innovation advantage, and business performance. International Journal of Operations \& Production Management, 36(9), 974994. http://dx.doi.org/10.1108/IJOPM-11-2014-0537.

Queiroz, S. A., Mendes, G. H., Silva, J. H., Ganga, G. M., Miguel, P. A. C., \& Oliveira, M. G. (2020). Servitization and performance: impacts on small and medium enterprises. Journal of Business and Industrial Marketing, 35(7), 1237-1249. http://dx.doi.org/10.1108/JBIM-062019-0277.

Rodríguez, A., Nieto, M. J., \& Santamaría, L. (2018). International collaboration and innovation in professional and technological knowledge-intensive services. Industry and Innovation, 25(4), 408-431. http://dx.doi.org/10.1080/13662716.2017.1414752.

Rong, D., \& Ming, X. (2014). Radical service innovation: influencing factors and mode selection Asian Social Science, 10(18), 210. http://dx.doi.org/10.5539/ass.v10n18p210.

Ryu, H. S., \& Lee, J. N. (2016). Innovation patterns and their effects on firm performance. Service Industries Journal, 36(3-4), 81-101. http://dx.doi.org/10.1080/02642069.2016.1155114.

Ryu, H. S., \& Lee, J. N. (2018). Understanding the role of technology in service innovation: comparison of three theoretical perspectives. Information \& Management, 55(3), 294-307. http://dx.doi.org/10.1016/j.im.2017.08.003.

Salunke, S., Weerawardena, J., \& McColl-Kennedy, J. R. (2011). Towards a model of dynamic capabilities in innovation-based competitive strategy: insights from project-oriented service firms. Industrial Marketing Management, 40(8), 1251-1263. http://dx.doi.org/10.1016/j.indmarman.2011.10.009.

Salunke, S., Weerawardena, J., \& McColl-Kennedy, J. R. (2019). The central role of knowledge integration capability in service innovation-based competitive strategy. Industrial Marketing Management, 76, 144-156. http://dx.doi.org/10.1016/j.indmarman.2018.07.004.

Santamaría, L., Nieto, M. J., \& Miles, I. (2012). Service innovation in manufacturing firms: evidence from Spain. Technovation, 32(2), 144-155. http://dx.doi.org/10.1016/j.technovation.2011.08.006.

Santos-Vijande, M. L., López-Sánchez, J. Á., \& Pascual-Fernandez, P. (2018). Co-creation with customers of hotel services: the moderating role of top management support. Current Issues in Tourism, 21(3), 301-327. http://dx.doi.org/10.1080/13683500.2015.1078781.

Scheuing, E. E., \& Johnson, E. M. (1989). A proposed model for new service development. Journal of Services Marketing, 3(2), 25-34. http://dx.doi.org/10.1108/EUM0000000002484.

Seegy, U., Gleich, R., Wald, A., Mudde, P., \& Motwani, J. (2008). The management of service innovation: an empirical investigation. International Journal of Services and Operations Management, 4(6), 672-686. http://dx.doi.org/10.1504/IJSOM.2008.018722.

Segarra-Ciprés, M., \& Bou-Llusar, J. C. (2018). External knowledge search for innovation: the role of firms' innovation strategy and industry context. Journal of Knowledge Management, 22(2), 280-298. http://dx.doi.org/10.1108/JKM-03-2017-0090.

Siahtiri, V. (2018). Innovation at the service encounter in knowledge intensive business services: antecedents and boundary conditions. Journal of Product Innovation Management, 35(5), 742-762. http://dx.doi.org/10.1111/jpim.12446.

Sillanpää, E., \& Junnonen, J. M. (2012). Factors affecting service innovations in FM service sector. Facilities, 30(11/12), 517-530. http://dx.doi.org/10.1108/02632771211252342.

Sindakis, S., \& Kitsios, F. (2016). Entrepreneurial dynamics and patient involvement in service innovation: developing a model to promote growth and sustainability in mental health care. Journal of the Knowledge Economy, 7(2), 545-564. http://dx.doi.org/10.1007/s13132-0140228-1. 
Singh, S., Akbani, I., \& Dhir, S. (2020). Service innovation implementation: a systematic review and research agenda. Service Industries Journal, 40(7-8), 1-27.

http://dx.doi.org/10.1080/02642069.2020.1731477.

Sjödin, D., Parida, V., Kohtamäki, M., \& Wincent, J. (2020). An agile co-creation process for digital servitization: A micro-service innovation approach. Journal of Business Research, 112, 478-491. http://dx.doi.org/10.1016/j.jbusres.2020.01.009.

Snyder, H., Witell, L., Gustafsson, A., Fombelle, P., \& Kristensson, P. (2016). Identifying categories of service innovation: A review and synthesis of the literature. Journal of Business Research, 69(7), 2401-2408. http://dx.doi.org/10.1016/j.jbusres.2016.01.009.

Sridhar, M., \& Ganesan, P. (2015). Service innovation barriers and facilitators and their effects on customer satisfaction and relationship improvement. International Journal of Services and Operations Management, 21(1), 87-111. http://dx.doi.org/10.1504/IJSOM.2015.068702.

Storey, C. D., \& Easingwood, C. J. (1996). Determinants of new product performance. International Journal of Service Industry Management, 7(1), 32-55. http://dx.doi.org/10.1108/09564239610109401.

Storey, C. D., \& Kahn, K. B. (2010). The role of knowledge management strategies and task knowledge in stimulating service innovation. Journal of Service Research, 13(4), 397-410. http://dx.doi.org/10.1177/1094670510370988.

Storey, C. D., Cankurtaran, P., Papastathopoulou, P., \& Hultink, E. J. (2016). Success factors for service innovation: A meta-analysis. Journal of Product Innovation Management, 33(5), 527-548. http://dx.doi.org/10.1111/jpim.12307.

Storey, C., \& Hughes, M. (2013). The relative impact of culture, strategic orientation and capability on new service development performance. European Journal of Marketing, 47(56), 833-856. http://dx.doi.org/10.1108/03090561311306903.

Suh, Y., \& Kim, M. S. (2012). Effects of SME collaboration on R\&D in the service sector in open innovation. Innovation, 14(3), 349-362. http://dx.doi.org/10.5172/impp.2012.14.3.349.

Tajeddini, K., Altinay, L., \& Ratten, V. (2017). Service innovativeness and the structuring of organizations: the moderating roles of learning orientation and inter-functional coordination. International Journal of Hospitality Management, 65, 100-114. http://dx.doi.org/10.1016/j.ijhm.2017.06.010.

Tang, T. W. (2016). Making innovation happen through building social capital and scanning environment. International Journal of Hospitality Management, 56, 56-65. http://dx.doi.org/10.1016/j.ijhm.2016.04.002.

Tang, T. W., Wang, M. C. H., \& Tang, Y. Y. (2015). Developing service innovation capability in the hotel industry. Service Business, 9(1), 97-113. http://dx.doi.org/10.1007/s11628-0130220-z.

Teece, D. J. (2007). Explicating dynamic capabilities: the nature and microfoundations of (sustainable) enterprise performance. Strategic Management Journal, 28(13), 1319-1350. http://dx.doi.org/10.1002/smj.640.

Temel, S., Mention, A. L., \& Torkkeli, M. (2013). The impact of cooperation on firms' innovation propensity in emerging economies. Journal of Technology Management \& Innovation, 8(1), 54-64. http://dx.doi.org/10.4067/S0718-27242013000100006.

Thakur, R., \& Hale, D. (2013). Service innovation: A comparative study of US and Indian service firms. Journal of Business Research, 66(8), 1108-1123. http://dx.doi.org/10.1016/j.jbusres.2012.03.007.

Thanasopon, B., Papadopoulos, T., \& Vidgen, R. (2018). How do firms open up the front-end of service innovation? A case study of IT-based service firms in Thailand. International Journal of Innovation Management, 22(01), 1850010. http://dx.doi.org/10.1142/S136391961850010X. 
Thwaites, D., \& Edgett, S. (1991). Aspects of innovation in a turbulent market environment: empirical evidence from UK building societies. Service Industries Journal, 11(3), 346-361. http://dx.doi.org/10.1080/02642069100000050.

Tomaszewski, L. A., Lacerda, D. P., \& Teixeira, R. (2016). Estratégia de operações em serviços de saúde preventiva: análise dos critérios competitivos e recomendações operacionais. Gestão \& Produção, 23(2), 381-396. http://dx.doi.org/10.1590/0104-530x0827-15.

Tai Tsou, H. (2012). Collaboration competency and partner match for e-service product innovation through knowledge integration mechanisms. Journal of Service Management, 23(5), 640-663. http://dx.doi.org/10.1108/09564231211269810.

Tsou, H. T., \& Chen, J. S. (2012). The influence of interfirm codevelopment competency on eservice innovation. Information \& Management, 49(3-4), 177-189. http://dx.doi.org/10.1016/j.im.2012.04.001.

Tu, C., Hwang, S. N., \& Wong, J. Y. (2014). How does cooperation affect innovation in microenterprises? Management Decision, 52(8), 1390-1409. http://dx.doi.org/10.1108/MD-072013-0388.

Tuzovic, S., Wirtz, J., \& Heracleous, L. (2018). How do innovators stay innovative? A longitudinal case analysis. Journal of Services Marketing, 32(1), 34-45. http://dx.doi.org/10.1108/JSM-02-2017-0052.

Van Riel, A. C., Lemmink, J., \& Ouwersloot, H. (2004). High-technology service innovation success: a decision-making perspective. Journal of Product Innovation Management, 21(5), 348-359. http://dx.doi.org/10.1111/j.0737-6782.2004.00087.x.

Vandermerwe, S., \& Rada, J. (1988). Servitization of business: adding value by adding services. European Management Journal, 6(4), 314-324. http://dx.doi.org/10.1016/02632373(88)90033-3.

Vargo, S. L., \& Akaka, M. A. (2012). Value cocreation and service systems (re)formation: A service ecosystems view. Service Science, 4(3), 207-217. http://dx.doi.org/10.1287/serv.1120.0019.

Vargo, S. L., \& Lusch, R. F. (2004). The four service marketing myths: remnants of a goodsbased, manufacturing model. Journal of Service Research, 6(4), 324-335. http://dx.doi.org/10.1177/1094670503262946.

Vasconcellos, L. H. R., \& Marx, R. (2011). Como ocorrem as inovações em serviços? Um estudo exploratório de empresas no Brasil. Gestão \& Produção, 18(3), 443-460. http://dx.doi.org/10.1590/S0104-530X2011000300001.

Vendrell-Herrero, F., Gomes, E., Bustinza, O. F., \& Mellahi, K. (2018). Uncovering the role of cross-border strategic alliances and expertise decision centralization in enhancing productservice innovation in MMNEs. International Business Review, 27(4), 814-825. http://dx.doi.org/10.1016/j.ibusrev.2018.01.005.

Verdu-Jover, A. J., Alos-Simo, L., \& Gomez-Gras, J. M. (2018). Adaptive culture and product/service innovation outcomes. European Management Journal, 36(3), 330-340. http://dx.doi.org/10.1016/j.emj.2017.07.004.

Vermeulen, P. A. (2005). Uncovering barriers to complex incremental product innovation in small and medium-sized financial services firms. Journal of Small Business Management, 43(4), 432-452. http://dx.doi.org/10.1111/j.1540-627X.2005.00146.x.

Vermeulen, P. A., De Jong, J. P., \& O'shaughnessy, K. C. (2005). Identifying key determinants for new product introductions and firm performance in small service firms. Service Industries Journal, 25(5), 625-640. http://dx.doi.org/10.1080/02642060500100783.

Vermeulen, P. A., Van Den Bosch, F. A., \& Volberda, H. W. (2007). Complex incremental product innovation in established service firms: A micro institutional perspective. Organization Studies, 28(10), 1523-1546. http://dx.doi.org/10.1177/0170840607068082. 
Wang, Q., Zhao, X., \& Voss, C. (2016). Customer orientation and innovation: A comparative study of manufacturing and service firms. International Journal of Production Economics, 171, 221-230. http://dx.doi.org/10.1016/j.ijpe.2015.08.029.

Wikhamn, W., Armbrecht, J., \& Remneland Wikhamn, B. (2018). Innovation in Swedish hotels. International Journal of Contemporary Hospitality Management, 30(6), 2481-2498. http://dx.doi.org/10.1108/IJCHM-06-2017-0323.

Witell, L., Snyder, H., Gustafsson, A., Fombelle, P., \& Kristensson, P. (2016). Defining service innovation: A review and synthesis. Journal of Business Research, 69(8), 2863-2872. http://dx.doi.org/10.1016/j.jbusres.2015.12.055.

Wu, M. J., Lin, Y. F., Liu, F. M., \& Hsiao, S. L. (2010). Overcoming service innovation bottlenecks using Web 2.0. Expert Systems with Applications, 37(11), 7373-7379. http://dx.doi.org/10.1016/j.eswa.2010.04.030.

Wünderlich, N. V., Heinonen, K., Ostrom, A. L., Patricio, L., Sousa, R., Voss, C., \& Lemmink, J. G. (2015). "Futurizing" smart service: implications for service researchers and managers. Journal of Services Marketing, 29(6-7), 442-447. http://dx.doi.org/10.1108/JSM-01-20150040.

Yang, Y., Lee, P. K., \& Cheng, T. C. E. (2016). Continuous improvement competence, employee creativity, and new service development performance: A frontline employee perspective. International Journal of Production Economics, 171, 275-288. http://dx.doi.org/10.1016/j.ijpe.2015.08.006.

Yeh, S. T., \& Walter, Z. (2017). Determinants of service innovation in academic libraries through the lens of disruptive innovation. College \& Research Libraries, 77(6), 795-804. http://dx.doi.org/10.5860/crl.77.6.795.

Zach, F. (2012). Partners and innovation in American destination marketing organizations. Journal of Travel Research, 51(4), 412-425. http://dx.doi.org/10.1177/0047287511426340.

Zhang, W., Wang, D., \& Zhao, Y. (2015). The effects of ties with service intermediaries on service and product innovations in Chinese manufacturing firms: the mediations of innovation search. Asian Journal of Technology Innovation, 23(3), 335-350. http://dx.doi.org/10.1080/19761597.2015.1120503.

Zhang, X., Chen, H., Wang, W., \& Ordóñez de Pablos, P. (2016). What is the role of IT in innovation? A bibliometric analysis of research development in IT innovation. Behaviour \& Information Technology, 35(12), 1130-1143. http://dx.doi.org/10.1080/0144929X.2016.1212403.

Zhao, Y., Zhou, R., \& Ci, Y. (2017). Factors influencing service innovation of MSNs in China: a theoretical and empirical research. Library Hi Tech, 35(3), 368-385. http://dx.doi.org/10.1108/LHT-09-2016-0106. 